\title{
Stream restoration and sewers impact sources and fluxes of water, carbon, and nutrients in urban watersheds
}

\author{
Michael J. Pennino ${ }^{1}$, Sujay S. Kaushal ${ }^{2}$, Paul M. Mayer ${ }^{1}$, Ryan M. Utz ${ }^{3}$, and Curtis A. Cooper ${ }^{4}$ \\ ${ }^{1}$ US EPA, Office of Research and Development, National Health and Environmental Effects Research Laboratory, \\ Western Ecology Division, Corvallis, OR, USA \\ ${ }^{2}$ University of Maryland, Department of Geology and Earth Systems Science \\ Interdisciplinary Center, College Park, MD, USA \\ ${ }^{3}$ Chatham University, Falk School of Sustainability, Pittsburgh, PA, USA \\ ${ }^{4}$ Washington Department of Ecology, Environmental Assessment Program, Olympia, WA, USA
}

Correspondence to: Michael J. Pennino (michael.pennino@gmail.com)

Received: 15 October 2015 - Published in Hydrol. Earth Syst. Sci. Discuss.: 16 December 2015

Revised: 18 May 2016 - Accepted: 26 July 2016 - Published: 26 August 2016

\begin{abstract}
An improved understanding of sources and timing of water, carbon, and nutrient fluxes associated with urban infrastructure and stream restoration is critical for guiding effective watershed management globally. We investigated how sources, fluxes, and flowpaths of water, carbon $(\mathrm{C})$, nitrogen $(\mathrm{N})$, and phosphorus $(\mathrm{P})$ shift in response to differences in urban stream restoration and sewer infrastructure. We compared an urban restored stream with two urban degraded streams draining varying levels of urban development and one stream with upland stormwater management systems over a 3-year period. We found that there was significantly decreased peak discharge in response to precipitation events following stream restoration. Similarly, we found that the restored stream showed significantly lower $(p<0.05)$ monthly peak runoff $\left(9.4 \pm 1.0 \mathrm{~mm} \mathrm{day}^{-1}\right)$ compared with two urban degraded streams (ranging from $44.9 \pm 4.5$ to $55.4 \pm 5.8 \mathrm{~mm} \mathrm{day}^{-1}$ ) draining higher impervious surface cover, and the stream-draining stormwater management systems and less impervious surface cover in its watershed $\left(13.2 \pm 1.9 \mathrm{~mm} \mathrm{day}^{-1}\right)$. The restored stream exported most carbon, nitrogen, and phosphorus at relatively lower streamflow than the two more urban catchments, which exported most carbon and nutrients at higher streamflow. Annual exports of total carbon $\left(6.6 \pm 0.5 \mathrm{~kg} \mathrm{ha}^{-1} \mathrm{yr}^{-1}\right)$, total nitrogen $\left(4.5 \pm 0.3 \mathrm{~kg} \mathrm{ha}^{-1} \mathrm{yr}^{-1}\right)$, and total phosphorus $\left(161 \pm 15 \mathrm{~kg} \mathrm{ha}^{-1} \mathrm{yr}^{-1}\right)$ were significantly lower in the restored stream compared to both urban degraded streams $(p<0.05)$, but statistically similar to the stream draining
\end{abstract}

stormwater management systems, for $\mathrm{N}$ exports. However, nitrate isotope data suggested that $55 \pm 1 \%$ of the nitrate in the urban restored stream was derived from leaky sanitary sewers (during baseflow), statistically similar to the urban degraded streams. These isotopic results as well as additional tracers, including fluoride (added to drinking water) and iodide (contained in dietary salt), suggested that groundwater contamination was a major source of urban nutrient fluxes, which has been less considered compared to upland sources. Overall, leaking sewer pipes are a problem globally and our results suggest that combining stream restoration with restoration of aging sewer pipes can be critical to more effectively minimizing urban nonpoint nutrient sources. The sources, fluxes, and flowpaths of groundwater should be prioritized in management efforts to improve stream restoration by locating hydrologic hot spots where stream restoration is most likely to succeed.

\section{Introduction}

Urbanization significantly increases impervious surface cover (ISC), alters hydrologic regimes, and contributes to elevated organic carbon and nutrient exports in streams and rivers (e.g., Kaushal and Belt, 2012; Paul and Meyer, 2001; Walsh et al., 2005b). The growing impacts of urbanization on watershed nutrient exports have contributed to coastal eutrophication and hypoxia both regionally and globally 
(Nixon et al., 1996; Petrone, 2010). However, urban watersheds can differ significantly in carbon and nutrient sources and fluxes, and there are major questions regarding the potential influence of stream restoration and sewer infrastructure on the sources and fluxes of nutrients (e.g., Bernhardt et al., 2005; McMillan and Vidon, 2014; Passeport et al., 2013). Here, we characterize changes in streamflow variability pre- and post-restoration in an urban stream. We also compare sources and timing of fluxes of water, carbon, and nutrients in the urban restored stream with several urban degraded streams of varying levels of upland stormwater management and impervious surface cover.

The potential for increasing urbanization and climate change to alter hydrology and nutrient fluxes is a problem for cities globally (Julian and Gardner, 2014; Kaushal et al., 2014b; Old et al., 2006; Smith and Smith, 2015; Walsh et al., 2005a). It is well known that hydrologically connected impervious surfaces in urban watersheds create hydrologic regimes characterized by flow events with higher peaks, quicker time to peak, and shorter falling limbs - hereafter referred to as a "flashy" system (Konrad et al., 2005; Loperfido et al., 2014; Meierdiercks et al., 2010; Smith et al., 2013; Sudduth et al., 2011b; Walsh et al., 2005b). Yet, little is known regarding the influence of stream restoration on hydrologic flashiness. Also, more work is necessary to characterize variability in fluxes of carbon and nutrients among urban watersheds, particularly for pulses (large changes in concentrations and fluxes over relatively short timescales) in urban restored and degraded streams (Kaushal et al., 2014b). Previous work indicates that pulses in carbon and nutrient exports can be influenced by the degree of hydrologic connectivity with impervious surfaces, sewer and stormwater infrastructure, and stream restoration features (e.g., Kaushal et al., 2014a; Newcomer et al., 2014). A recent global review and synthesis suggests that certain forms of stream restoration have potential to retain watershed nutrient exports particularly during baseflow, but further evaluation across streamflow is necessary (Newcomer-Johnson et al., 2016). Although stream restoration research is growing, the effects of stream restoration on minimizing pulses of water, carbon, and nutrient exports is still not clearly understood (Filoso and Palmer, 2011; Harrison et al., 2014; Newcomer et al., 2014).

One key to improved management of urban watersheds is a better understanding of contaminant sources and how they can shift across hydrologic variability in restored and urban degraded streams. Knowledge of the sources of chemical fluxes in urban restored streams is particularly lacking, even though stream restoration is currently a billion-dollar industry in the US (Bernhardt et al., 2005). In order to characterize contaminant sources, various biogeochemical and hydrologic tracers have been employed in other urban degraded watersheds. For example, recent studies have utilized $\mathrm{N}$ and $\mathrm{O}$ stable isotopes to determine sources of $\mathrm{NO}_{3}^{-}$(e.g., wastewater, atmospheric, or nitrification) (Burns et al., 2009; Kaushal et al., 2011; Kendall et al., 2007) in urban streams and rivers.
Tracking $\mathrm{NO}_{3}^{-}$can be improved when used in conjunction with additional tracers such as anions like fluoride and iodide (Kaushal et al., 2014a), where fluoride is applied as an additive to drinking water (Dean et al., 1950) and iodide is used in table salt (Waszkowiak and Szymandera-Buszka, 2008); therefore, their presence in streams may be considered an indicator of contamination by wastewater. Others have used fluorescence spectroscopy to determine dissolved organic matter sources and quality (e.g., labile vs. recalcitrant) (Baker, 2001; Cory et al., 2010; Smith and Kaushal, 2015), and to trace wastewater sources. Finally, stable isotopes of water have been used to characterize groundwater vs. surface water flowpaths (Gat, 1996; Harris et al., 1999; Kendall and Coplen, 2001). These techniques and others have been used globally to detect the influence of leaky sewer infrastructure on water quality (Ekklesia et al., 2015; Hall et al., 2016; Risch et al., 2015; Tran et al., 2014; Wolf et al., 2012) and it has been shown that sewer leaks have impacts during baseflow and stormflow (Divers et al., 2013, 2014; Phillips and Chalmers, 2009; Rose, 2007). The present study is unique in that it uses multiple tracers of contaminants to assess the effects of hydrologic variability on sources and fluxes of carbon and nutrients.

The objectives of this study were to characterize sources and timing of water, carbon, and nutrient fluxes in four urban watersheds with varying urban development and water management, including one site with extensive stream restoration. Our first objective was to compare the hydrologic response of the restored stream to precipitation events pre- and post-restoration. We predicted that the stream restoration, which reconnected the stream with its floodplain, had the potential to impact peak discharge and attenuate flashy flows. This would be due to the bankfull discharge overflowing onto the floodplain and infiltrating the floodplain soil and increasing groundwater contributions to baseflow (Bohnke et al., 2002; Cendon et al., 2010; Hester and Gooseff, 2010). In fact, floodplain reconnection is an a priori objective in restored streams in Baltimore, Maryland, USA and elsewhere globally (Banach et al., 2009; Duerksen et al., 2005; GreenmanPedersen Inc., 2003; Hoffmann et al., 2011; Klocker et al., 2009; Lamouroux et al., 2015). Our second objective was to compare metrics of hydrologic flashiness, and sources and timing of chemical fluxes in this restored urban stream with two urban degraded streams draining varying levels of urban development and one stream with extensive stormwater management systems in its catchment to assess the role of stream restoration and potential pollutant sources, such as leaky sanitary sewers. Research was conducted in watersheds that are part of the Baltimore Long-Term Ecological Research (BES LTER) project, which is described further below and elsewhere (www.beslter.org) (e.g., Groffman et al., 2004; Kaushal et al., 2011; Lindner and Miller, 2012; Meierdiercks et al., 2010; Ryan et al., 2010). 


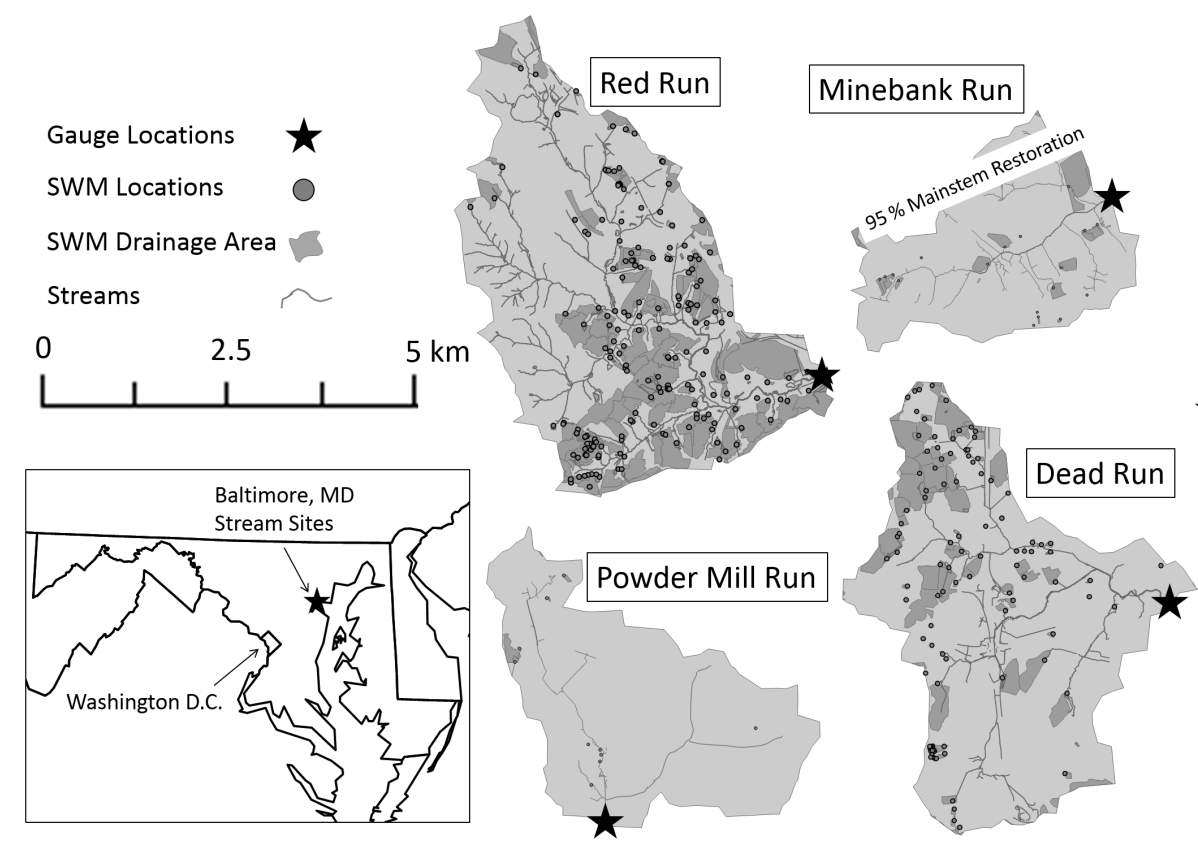

Figure 1. Site map showing the four stream sites in the Baltimore, MD, region and the SWM locations within each watershed. SWM features are based on 2009 data from the Baltimore County Department of Environmental Protection and Sustainability.

\section{Methods}

\subsection{Site descriptions}

All watersheds were located in the metropolitan region of Baltimore, Maryland, USA, in the Chesapeake Bay watershed (Fig. 1). Impervious surface cover (ISC) was calculated for each watershed using ArcGIS and based on averaging the ISC values obtained from the 2006 National Land Cover Database (NLCD), a $2 \mathrm{~m}$ satellite imagery obtained from the University of Vermont, and a roads and buildings polygon layer for Baltimore County. The amount of stormwater management (SWM) within each watershed was characterized using ArcGIS as the percentage of watershed drainage area that is managed by stormwater management systems. Data on the locations of SWM systems and the drainage area controlled by each SWM facility were provided by the Baltimore County, Maryland Department of Environmental Protection and Sustainability (BCMDEPS).

Four streams were chosen for this study: Minebank Run (MBR), an urban restored stream; Red Run (RRN), a stream with extensive upland SWM systems in its watershed; Dead Run (DRN), an urban degraded stream with upland SWM systems; and Powder Mill Run (PMR), an urban degraded stream with no SWM or stream restoration (Table 1). Details on the four watersheds in this study can be found in Table 1, with information on the \% ISC, \% SWM, median year built for development, range of flows, and range of flows sampled. DRN and PMR have the highest \% ISC (45.7\% and $44.3 \%$, respectively), while MBR has intermediate $\%$
ISC (29.4\%), and RRN has the lowest \% ISC (20.5\%) (Table 1). RRN has approximately $40 \%$ SWM and DRN has $33 \%$ SWM, while MBR and PMR have minimal SWM in their watersheds (Table 1).

About $95 \%$ of Minebank Run's mainstem has been restored ( 5700 linear meters were restored, BCMDEPS); the headwaters were restored in 1998-1999 and the lower portions (directly above and below the stream gauge) were restored in 2004-2005. Restoration features at MBR include oxbows, redesigned channels, armoring, low connected floodplains, increased sinuosity, and step pools (Harrison et al., 2011; Kaushal et al., 2008b). The stormwater management at RRN is primarily in the lower portion of the watershed and includes detention ponds, wet ponds, bioretention, and sand filters, with its headwaters containing a quarry and low-density development on septic systems (BCMDEPS). DRN has stormwater management mainly in a portion of its headwaters, with primarily detention ponds (Fig. 1, Table 1, Smith et al., 2015). Also, RRN and MBR have broader undeveloped downstream riparian zones than either DRN or PMR.

Discharge was measured continuously at all of the four study watersheds: Minebank Run, Powder Mill Run, and Dead Run are gauged by the US Geological Survey (USGS gage numbers 0158397967, 01589305, and 01589330, respectively), while Red Run is gauged by the University of Maryland, Baltimore County Center for Urban Environmental Research and Education. Further details on stream site characteristics and the methods described below are in the Supplement. 
Table 1. Site characteristics for the four urban watersheds.

\begin{tabular}{llccccrrr}
\hline Site & Status & $\begin{array}{c}\text { Median } \\
\text { year of } \\
\text { development* }\end{array}$ & $\begin{array}{r}\text { Stream } \\
\text { length } \\
(\mathrm{km})\end{array}$ & $\begin{array}{r}\text { Area } \\
\left(\mathrm{km}^{2}\right)\end{array}$ & $\begin{array}{r}\text { ISC } \\
(\%)\end{array}$ & $\begin{array}{r}\text { Range of } \\
\text { flows sampled } \\
\left(\mathrm{L} \mathrm{s}^{-1}\right)\end{array}$ & $\begin{array}{r}\text { Range of } \\
\text { flows } \\
\left.(\mathrm{L} \mathrm{s})^{-1}\right)\end{array}$ & $\begin{array}{r}\text { Drainage area } \\
\text { controlled by } \\
\text { SWM }(\%)\end{array}$ \\
\hline $\begin{array}{l}\text { Minebank } \\
\text { Run (MBR) }\end{array}$ & $\begin{array}{l}\text { Older urban } \\
\text { restored }\end{array}$ & 1959 & 4.6 & 5.3 & 29.4 & $10-396$ & $4.8-3115$ & 17.8 \\
\hline $\begin{array}{l}\text { Red Run } \\
\text { (RRN) }\end{array}$ & $\begin{array}{l}\text { Newer urban } \\
\text { with SWM }\end{array}$ & 1998 & 7.7 & 19.1 & 20.5 & $65-2714$ & $17-16930$ & 40.4 \\
\hline $\begin{array}{l}\text { Powder Mill } \\
\text { Run (PMR) }\end{array}$ & $\begin{array}{l}\text { Older urban with } \\
\text { no management }\end{array}$ & 1954 & 4.8 & 9.4 & 44.3 & $15-934$ & $12-9061$ & 0.7 \\
\hline $\begin{array}{l}\text { Dead Run } \\
\text { (DRN) }\end{array}$ & $\begin{array}{l}\text { Older urban } \\
\text { with SWM }\end{array}$ & 1963 & 8.0 & 14.3 & 45.7 & $17-1897$ & $12-20274$ & 32.5 \\
\hline
\end{tabular}

Land use data from NLCD 2001. ISC indicates impervious surface cover; \% ISC is averaged from the $2001 \mathrm{NLCD}$, a $2 \mathrm{~m}$ satellite imagery obtained from the University of Vermont, and a roads and buildings polygon layer for Baltimore County; SWM indicates stormwater management. * Median year of development is based on the median year built for houses within each watershed. Further information on land use can be found in the Supplement.

\subsection{Comparison of pre- and post-restoration hydrologic response}

In order to examine the hydrologic response of an urban stream to restoration, the relationship between effective precipitation (Ppt) and effective peak discharge $\left(Q_{\mathrm{pk}}\right)$ was estimated for Minebank Run pre- and post-restoration from 2001 to 2008. Discharge and precipitation data used in this analysis were from the US Geological Survey (USGS) National Water Information System.

There were 195 pre-restoration and 221 post-restoration dates used in the effective Ppt- $Q_{\mathrm{pk}}$ analysis (where the designation of effective is used to specifically identify data that meet the assumptions of a measurable mechanism between precipitation leading to a discharge response). Regression lines were created in Minitab (release 14.2, Minitab, Inc. State College, PA, USA) to compare the precipitation amount $\left(\mathrm{mm} \mathrm{day}^{-1}\right)$ with its associated daily peak discharge $(\mathrm{cms})$ for the pre-restoration and the post-restoration data. Slope and intercept of these developed regression lines were compared using a general linear model in Minitab (ID 1248). See the Supplement for further details.

\subsection{Water quality sampling and analyses}

Water samples were collected at the MBR, RRN, DRN, and PMR stream gauge locations every 2-4 weeks (called "routinely sampled" water quality data from this point on) for 3 years (2010-2012) and longitudinally at 8-12 sampling points (300-1000 $\mathrm{m}$ apart) from the mouth to headwaters of each stream network during four different seasons: two winters (January 2010 and December 2010), one spring (April 2010), and one summer (June 2011). Samples were analyzed for total organic C (TOC), dissolved organic C (DOC), total Kjeldahl nitrogen (TKN), nitrate plus nitrite $\left(\mathrm{NO}_{3}^{-}+\mathrm{NO}_{2}^{-}\right)$, total phosphorus (TP), orthophosphate $\left(\mathrm{PO}_{4}^{3-}\right)$, iodide $\left(\mathrm{I}^{-}\right)$, fluoride $\left(\mathrm{F}^{-}\right)$, stable water isotopes $\left(\delta^{2} \mathrm{H}-\mathrm{H}_{2} \mathrm{O}\right.$ and $\delta^{18} \mathrm{O}$ $\mathrm{H}_{2} \mathrm{O}$, details below), $\mathrm{C}$ quality characterization (described further below), and $\mathrm{NO}_{3}^{-}$stable isotopes $\left(\delta^{15} \mathrm{~N}-\mathrm{NO}_{3}^{-}\right.$and $\delta^{18} \mathrm{O}-\mathrm{NO}_{3}^{-}$, details below). All samples were analyzed using standard Environmental Protection Agency (EPA) methods by the US EPA National Risk Management Research Laboratory in Ada, Oklahoma, USA.

\subsection{Nitrate and water stable isotope analyses and mixing models}

Surface samples for $\delta^{15} \mathrm{~N}-\mathrm{NO}_{3}^{-}$and $\delta^{18} \mathrm{O}-\mathrm{NO}_{3}^{-}$isotopes of dissolved $\mathrm{NO}_{3}^{-}$were filtered $(0.45 \mu \mathrm{m})$, frozen, and shipped to the UC Davis Stable Isotope Facility (SIF) for analysis. The isotope composition of nitrate was measured following the denitrifier method (Casciotti et al., 2002; Sigman et al., 2001). Briefly, denitrifying bacteria were used to convert nitrate in water samples to $\mathrm{N}_{2} \mathrm{O}$ gas, which was then analyzed by a mass spectrometer for stable isotopic ratios of $\mathrm{N}$ and $\mathrm{O}$ of nitrate $\left({ }^{15} \mathrm{~N} /{ }^{14} \mathrm{~N}\right.$ and $\left.{ }^{18} \mathrm{O} /{ }^{16} \mathrm{O}\right)$. Values for $\delta^{15} \mathrm{~N}-\mathrm{NO}_{3}^{-}$ and $\delta^{18} \mathrm{O}-\mathrm{NO}_{3}^{-}$are reported as per mil (\%o) relative to atmospheric $\mathrm{N}_{2}\left(\delta^{15} \mathrm{~N}\right)$ or VSMOW $\left(\delta^{18} \mathrm{O}\right)$, according to $\delta^{15} \mathrm{~N}$ or $\delta^{18} \mathrm{O}(\% \circ)=[(R)$ sample $/(R)$ standard -1$] \times 1000$, where $R$ denotes the ratio of the heavy to light isotope $\left({ }^{15} \mathrm{~N} /{ }^{14} \mathrm{~N}\right.$ or ${ }^{18} \mathrm{O} /{ }^{16} \mathrm{O}$ ). For data correction and calibration, UC Davis SIF uses calibration nitrate standards (USGS 32, USGS 34, and USGS 35) supplied by NIST (National Institute of Standards and Technology, Gaithersburg, MD). The long-term standard deviation for nitrate isotope samples at UC Davis SIF is $0.4 \%$ for $\delta^{15} \mathrm{~N}-\mathrm{NO}_{3}^{-}$and $0.5 \%$ ofor $\delta^{18} \mathrm{O}-\mathrm{NO}_{3}^{-}$. Previous studies (Kaushal et al., 2011; Kendall et al., 2007) indicate that the relative amounts of $\delta^{15} \mathrm{~N}-\mathrm{NO}_{3}^{-}$and $\delta^{18} \mathrm{O}-\mathrm{NO}_{3}^{-}$ can be used to determine specific sources of nitrate (i.e., fertilizer, atmospheric, or sewage-derived nitrate).

Stable nitrate isotope data were used to create a three-endmember isotope mixing model to determine the percent con- 
tribution of different potential nitrate sources: wastewater, nitrification, or atmospheric-derived nitrate (Kaushal et al., 2011; Phillips, 2001), where

$f_{\text {wastewater }}=$
$\frac{\left(\delta^{15} \mathrm{~N}_{\mathrm{N}}-\delta^{15} \mathrm{~N}_{\mathrm{A}}\right)\left(\delta^{18} \mathrm{O}_{\mathrm{S}}-\delta^{18} \mathrm{O}_{\mathrm{A}}\right)-\left(\delta^{18} \mathrm{O}_{\mathrm{N}}-\delta^{18} \mathrm{O}_{\mathrm{A}}\right)\left(\delta^{15} \mathrm{~N}_{\mathrm{S}}-\delta^{15} \mathrm{~N}_{\mathrm{A}}\right)}{\left(\delta^{15} \mathrm{~N}_{\mathrm{N}}-\delta^{15} \mathrm{~N}_{\mathrm{A}}\right)\left(\delta^{18} \mathrm{O}_{\mathrm{W}}-\delta^{18} \mathrm{O}_{\mathrm{A}}\right)-\left(\delta^{18} \mathrm{O}_{\mathrm{N}}-\delta^{18} \mathrm{O}_{\mathrm{A}}\right)\left(\delta^{15} \mathrm{~N}_{\mathrm{W}}-\delta^{15} \mathrm{~N}_{\mathrm{A}}\right)}$

$f_{\text {Atmospheric }}=$

$\frac{\left(\delta^{15} \mathrm{~N}_{\mathrm{S}}-\delta^{15} \mathrm{~N}_{\mathrm{N}}\right)\left(\delta^{18} \mathrm{O}_{\mathrm{W}}-\delta^{18} \mathrm{O}_{\mathrm{N}}\right) \times f_{\text {wastewater }}}{\delta^{18} \mathrm{O}_{\mathrm{A}}-\delta^{18} \mathrm{O}_{\mathrm{N}}}$

$f_{\text {nitrification }}=1-f_{\text {wastewater }}-f_{\text {atmospheric }}$,

and $f_{\text {wastewater, }} f_{\text {atmospheric }}$, and $f_{\text {nitrification }}$ are the fractions of nitrate from wastewater, atmospheric, or nitrification sources, respectively (also equivalent to \% wastewater $\mathrm{NO}_{3}^{-}, \%$ atmospheric $\mathrm{NO}_{3}^{-}$, and $\%$ nitrification $\left.\mathrm{NO}_{3}^{-}\right) ; \delta^{15} \mathrm{~N}_{\mathrm{S}}$ or $\delta^{18} \mathrm{O}_{\mathrm{S}}$ is the value (\%o) for the nitrate sample; $\delta^{15} \mathrm{~N}_{\mathrm{N}}$ or $\delta^{18} \mathrm{O}_{\mathrm{N}}$ is the end-member value (\%o) for nitrification; $\delta^{15} \mathrm{~N}_{\mathrm{A}}$ or $\delta^{18} \mathrm{O}_{\mathrm{A}}$ is the end-member value $(\% \circ)$ for atmospheric nitrate; and $\delta^{15} \mathrm{~N}_{\mathrm{W}}$ or $\delta^{18} \mathrm{O}_{\mathrm{W}}$ is the end-member value (\%o) for wastewater nitrate. End-member values for $\delta^{15} \mathrm{~N}-\mathrm{NO}_{3}^{-}$and $\delta^{18} \mathrm{O}-\mathrm{NO}_{3}^{-}$for nitrification ( -3 and 0 , respectively) and atmospheric nitrate $(-0.2$ and 80 , respectively) were obtained from an average of the values in Kendall et al. (2007). The wastewater $\delta^{15} \mathrm{~N}-\mathrm{NO}_{3}^{-}$and $\delta^{18} \mathrm{O}-\mathrm{NO}_{3}^{-}$end-member value (35.4 and 13.3, respectively) was based on averaging the effluent nitrate isotope values measured from the Blue Plains waste water treatment plant in Washington D.C. (for monthly samples collected 2010-2011).

Water isotope $\left(\delta^{2} \mathrm{H}-\mathrm{H}_{2} \mathrm{O}\right.$ and $\left.\delta^{18} \mathrm{O}-\mathrm{H}_{2} \mathrm{O}\right)$ samples were collected from August 2010 to October 2011 and analyzed using a high temperature conversion elemental analyzer (TC/EA), a continuous flow unit, and an isotope ratio spectrometer (IRMS). A two-end-member mixing model (Buda and DeWalle, 2009; Kaushal et al., 2011; Williard et al., 2001) was created using $\delta^{18} \mathrm{O}-\mathrm{H}_{2} \mathrm{O}$ to distinguish between groundwater and atmospheric water sources, where

$\%$ groundwater $=\frac{\delta^{18} \mathrm{O}_{\mathrm{S}}-\delta^{18} \mathrm{O}_{\mathrm{R}}}{\delta^{18} \mathrm{O}_{\mathrm{G}}-\delta^{18} \mathrm{O}_{\mathrm{R}}} \times 100$,

and $\%$ rainwater $=100-\%$ groundwater, $\delta^{18} \mathrm{O}_{\mathrm{S}}$ is the value (\%o) for the streamwater sample, $\delta^{18} \mathrm{O}_{\mathrm{R}}$ is the end-member value (\%o) for rainwater, and $\delta^{18} \mathrm{O}_{\mathrm{G}}$ is the end-member value (\%o) for groundwater. End-member values for $\delta^{2} \mathrm{H}-\mathrm{H}_{2} \mathrm{O}$ and $\delta^{18} \mathrm{O}-\mathrm{H}_{2} \mathrm{O}$ from rainwater $(-22.41$ and -5.23 , respectively) and groundwater $(-44.02$, and -7.995 , respectively) were obtained from Kendall and Coplen (2001).

\subsection{Fluorescence analyses for dissolved organic matter characterization}

The lability (e.g., protein or humic-like) and sources (e.g., allochthonous or autochthonous) of dissolved organic mat- ter were characterized using fluorescence excitation emission matrices (EEMs) (Cory and McKnight, 2005; Cory et al., 2010), using a Fluoromax-4 spectrofluorometer (Horiba, Jobin Yvon). Water samples were analyzed with an excitation range of $240-450 \mathrm{~nm}$ at $10 \mathrm{~nm}$ increments and an emission range of $290-600 \mathrm{~nm}$ at $2 \mathrm{~nm}$ increments. Fluorescence EEMs were instrument corrected, blank subtracted, and normalized by the water Raman signal following Cory et al. (2010). Standard inner-filter corrections (IFC) were not performed on samples because absorbance measurements were not attained for most samples (however, for a subset of samples, absorbance was collected using a scanning spectrophotometer, the inner-filter corrections were done, and it was found that there is $<5 \%$ difference in the EEM metric results, with and without IFC). We analyzed fluorescence EEMs for the following indices: fluorescence index, FI (McKnight et al., 2001); humification index, HIX (Huguet et al., 2009; Zsolnay et al., 1999); biological freshness index, BIX (Huguet et al. 2009); and protein-to-humic fluorescence intensities ratio, $P / H$ ratio (Coble, 1996; Stolpe et al., 2010).

\subsection{Estimation of annual watershed carbon, nutrient, and anion exports}

Routinely sampled concentration data, mean daily discharge, and the USGS FORTRAN program LOADEST (Runkel et al., 2004) were used to calculate the annual exports of all stream chemistry variables at each site. For clarification, the term load is used when referring to mass per the amount of time, while exports is used when referring to loads normalized by watershed area. Various methods have been employed for estimating annual nutrient exports (e.g., Cohn, 1995; Schwartz and Naiman, 1999). However, we chose LOADEST because it uses a multiple parameter regression model that accounts for bias, data censoring, and non-normality to minimize difficulties in load estimation (Qian et al., 2007). LOADEST uses three different statistical approaches to estimate load: adjusted maximum likelihood estimation (AMLE), maximum likelihood estimation (MLE), and least absolute deviation (LAD). As suggested by Runkel et al. (2004), AMLE was chosen when the calibration model errors (residuals) were normally distributed, while LAD was chosen when residuals were not normally distributed. LOADEST produced load estimates for daily nutrient loads and annual exports were calculated by summing daily load for each year and dividing by watershed area. Through analyses of model residuals and a comparison of the observed and estimated loads, none of the constituents where found to have bias in the LOADEST output (Runkel, 2013). Based on the mean daily runoff and estimated daily loads, flow duration and nutrient duration curves were quantified for each stream similar to previous studies (Duan et al., 2012; Shields et al., 2008; Sivirichi et al., 2011). Following Shields et al. (2008), we also calculated the F75 metric for each nutrient export, which is the runoff at which $75 \%$ of 
each nutrient is exported annually. Additionally, $95 \%$ confidence intervals were estimated for annual exports using a simplified bootstrap resampling approach similar to Efron and Tibshirani (1986) and Rustomji and Wilkinson (2008).

Samples were collected over a range of streamflow conditions. However, the largest flows were not sampled due to adherence to a random sampling scheme and logistic feasibility (see Table 1, Fig. S2 in the Supplement). Flow duration records, based on mean daily flow for 2010-2012, show that the majority of samples were collected during low to intermediate flows (Fig. S2). As a result, the daily load estimates from LOADEST may not accurately reflect flows higher than the highest flows sampled. Also, because mean daily discharge data were used instead of instantaneous discharge, there is likely increased uncertainty in the daily load estimates during storm event peak flow periods. However, because all four sites are within the same city and receive relatively the same rainfall during storm events, the relative annual loads estimated for the sites are comparable and it is appropriate to draw conclusions among the four study sites. Also, Carey et al. (2014) found no difference in annual load estimates in an urban watershed when using daily vs. instantaneous records of flow and nitrate concentration, though it was a significantly larger suburbanizing watershed. There are also likely differences in the effects of storms on carbon $(\mathrm{C})$, nitrogen $(\mathrm{N})$, and phosphorus $(\mathrm{P})$ concentrations, since $\mathrm{NO}_{3}^{-}$is generally diluted during storms, whereas particulate organic nitrogen and $\mathrm{P}$ generally increases during storms (Bowes et al., 2005; Kaushal et al., 2008a). Additionally, when comparing the years sampled (2010-2012) to the full discharge record at each site (starting in 2001 for MBR, 2008 for RRN, 2005 for PMR, and 1998 for DRN), the range of streamflow during 2010-2012 contains 5 of the 10 highest flows recorded at all sites. Our sampling period also included streamflow equal to the lowest streamflow ever recorded at these gauges, indicating that 2010-2012 encompasses the full range of flows.

\subsection{Characterizing hydrologic flashiness and pulses of $\mathrm{C}, \mathrm{N}$, and $\mathrm{P}$ exports}

Metrics of hydrologic flashiness were calculated using daily and instantaneous discharge and precipitation data. Metrics consisted of the following variables: (1) average peak runoff, (2) hydrograph duration, (3) high-flow event frequency (monthly frequency of peaks above $3 \times$ monthly median) (Utz et al., 2011), (4) mean monthly peak flow coefficient of variation, and (5) mean lag time (time between rainfall centroid and peak runoff) (Smith et al., 2013). Additionally, mean daily discharge data were used to calculate the flashiness index (average daily change in mean daily streamflow per month, divided by the mean monthly flow) (Poff et al., 2006a; Sudduth et al., 2011b), which is identical to the R-B index (Baker et al., 2004). Peak flow runoff is the only metric that accounts for watershed size. These metrics were chosen to provide a sense of how variability in urbanization affects typical stormflow characteristics and the variability in hydrologic response to storm events. Precipitation data used for lag-time calculations were $15 \mathrm{~min}$ interval rainfall data obtained from the National Atmospheric and Ocean Administration (NOAA) National Climatic Data Center (NOAA, 2014).

We also quantified the variability of routinely sampled carbon and nutrient source and concentration data and the daily export data from USGS LOADEST by calculating (1) the mean monthly coefficient of variation, (2) the mean difference (absolute value of change between consecutive daily exports or routinely sampled nutrient concentrations), and (3) the flashiness index (described above). These metrics were chosen to determine how differences in urbanization affect the variability or pulsing of $\mathrm{C}$ and nutrient sources, concentrations, and exports over time.

\subsection{Statistical analyses}

In order to compare all time series data (routinely sampled nutrient concentrations, stable isotopes, carbon quality indices, and monthly flashiness metrics at each stream site), we used a repeated measures ANOVA and post-hoc pairwise comparisons for each site with the Wilcox test (also called the Mann-Whitney test). This is a non-parametric rank sum test considered better suited for censored and skewed data (Cooper et al., 2014; Helsel and Hirsch, 1992; Lloyd et al., 2014). We used $95 \%$ confidence intervals for pairwise annual export comparisons. Analysis of covariance (ANCOVA) was performed to test for differences in regression slopes. Statistical analysis of trends were examined using Sen's slope estimator and a Mann-Kendall test (Gilbert, 1987; Helsel and Hirsch, 2002). The Mann-Kendall test is a linear regression zero slope test of time-ordered data over time (Gilbert, 1987). Statistical analysis was performed using R software (R Development Core Team, 2013) or Minitab (Release 14.2, Minitab, Inc. State College, PA, USA), and MATLAB 8.1.0 (MATLAB and statistics toolbox release R2012a Student) was used for estimating hydrologic flashiness metrics in each stream for the period 2010-2012.

\section{Results}

\subsection{Pre-restoration and post-restoration hydrologic analysis}

Data from the analysis of the effective precipitation peak discharge relationship in MBR are shown in Fig. 2, for both the pre- and post-restoration periods (data during the restoration were not included in the analysis). The median storm depth was $7.6 \mathrm{~mm}$ during the pre-restoration period $(n=195)$ and $6.1 \mathrm{~mm}$ in the post-restoration period $(n=221)$. The median storm peak discharge was $0.7 \mathrm{cms}$ in the pre-restoration period $(n=195)$ and $0.4 \mathrm{cms}$ in the post-restoration period 
Table 2. Comparisons of water, carbon, and nitrate sources (mean $\pm \mathrm{SE}$ ) among the four urban watersheds.

\begin{tabular}{|c|c|c|c|c|}
\hline & MBR & RRN & PMR & DRN \\
\hline \multicolumn{5}{|l|}{ Water isotopes } \\
\hline$\delta^{2} \mathrm{H}-\mathrm{H}_{2} \mathrm{O}$ & $-43 \pm 1.8^{\mathrm{a}}$ & $-44 \pm 2.0^{\mathrm{a}}$ & $-43 \pm 2.5^{\mathrm{a}}$ & $-43 \pm 3.0^{\mathrm{a}}$ \\
\hline$\delta^{18} \mathrm{O}-\mathrm{H}_{2} \mathrm{O}$ & $-6.7 \pm 0.2^{\mathrm{a}}$ & $-6.9 \pm 0.2^{\mathrm{a}}$ & $-6.6 \pm 0.3^{\mathrm{a}}$ & $-6.6 \pm 0.4^{\mathrm{a}}$ \\
\hline$\%$ Groundwater & $50 \pm 5^{\mathrm{a}}$ & $57 \pm 6^{\mathrm{a}}$ & $47 \pm 6^{\mathrm{a}}$ & $40 \pm 7^{\mathrm{a}}$ \\
\hline \% Rainwater & $50 \pm 5^{\mathrm{a}}$ & $43 \pm 6^{\mathrm{a}}$ & $53 \pm 6^{\mathrm{a}}$ & $60 \pm 7^{a}$ \\
\hline \multicolumn{5}{|l|}{ Carbon quality } \\
\hline HIX & $0.87 \pm 0.01^{\mathrm{a}}$ & $0.81 \pm 0.02^{\mathrm{b}}$ & $0.80 \pm 0.01^{\mathrm{c}}$ & $0.83 \pm 0.02^{\mathrm{ab}}$ \\
\hline BIX & $0.73 \pm 0.04^{\mathrm{a}}$ & $0.64 \pm 0.03^{b}$ & $0.75 \pm 0.04^{\mathrm{a}}$ & $0.78 \pm 0.04^{\mathrm{a}}$ \\
\hline FI & $1.20 \pm 0.05^{\mathrm{a}}$ & $1.15 \pm 0.05^{b c}$ & $1.16 \pm 0.05^{a c}$ & $1.26 \pm 0.05^{a c}$ \\
\hline$P / H$ ratio & $0.73 \pm 0.07^{\mathrm{ab}}$ & $0.66 \pm 0.06^{\mathrm{a}}$ & $1.11 \pm 0.10^{\mathrm{c}}$ & $0.89 \pm 0.10^{\mathrm{b}}$ \\
\hline \multicolumn{5}{|l|}{ Nitrate isotopes } \\
\hline$\delta^{15} \mathrm{~N}-\mathrm{NO}_{3}^{-}$ & $7.0 \pm 0.2^{\mathrm{ab}}$ & $6.3 \pm 0.2^{\mathrm{a}}$ & $8.1 \pm 0.2^{\mathrm{c}}$ & $7.5 \pm 0.2^{\mathrm{bc}}$ \\
\hline$\delta^{18} \mathrm{O}-\mathrm{NO}_{3}^{-}$ & $5.0 \pm 0.4^{\mathrm{a}}$ & $4.0 \pm 0.3^{b}$ & $5.9 \pm 0.6^{\mathrm{a}}$ & $8.0 \pm 0.9^{c}$ \\
\hline$\%$ Wastewater & $53 \pm 1.0^{\mathrm{a}}$ & $51 \pm 1.1^{\mathrm{a}}$ & $56 \pm 1.2^{\mathrm{b}}$ & $52 \pm 1.8^{\mathrm{ab}}$ \\
\hline$\%$ Atmospheric & $8.7 \pm 1.0^{\mathrm{ab}}$ & $7.6 \pm 1.0^{\mathrm{a}}$ & $9.4 \pm 1.7^{\mathrm{ab}}$ & $15 \pm 2.5^{\mathrm{b}}$ \\
\hline$\%$ Nitrification & $38 \pm 0.7^{\mathrm{a}}$ & $41 \pm 0.5^{\mathrm{b}}$ & $34 \pm 0.7^{\mathrm{c}}$ & $33 \pm 0.9^{c}$ \\
\hline
\end{tabular}

MBR indicates Minebank Run, RRN indicates Red Run, PMR indicates Powder Mill Run, DRN indicates Dead Run. Different letters $\left({ }^{\mathrm{a}},{ }^{\mathrm{b}},{ }^{\mathrm{c}}\right.$, or $\left.{ }^{\mathrm{d}}\right)$ indicate significant differences $(p<0.05)$, based on pairwise comparisons of 3 years of routinely sampled data. HIX indicates humification index; BIX indicates biological freshness index;

FI indicates fluorescence index; $P / H$ ratio indicates protein-to-humic ratio.

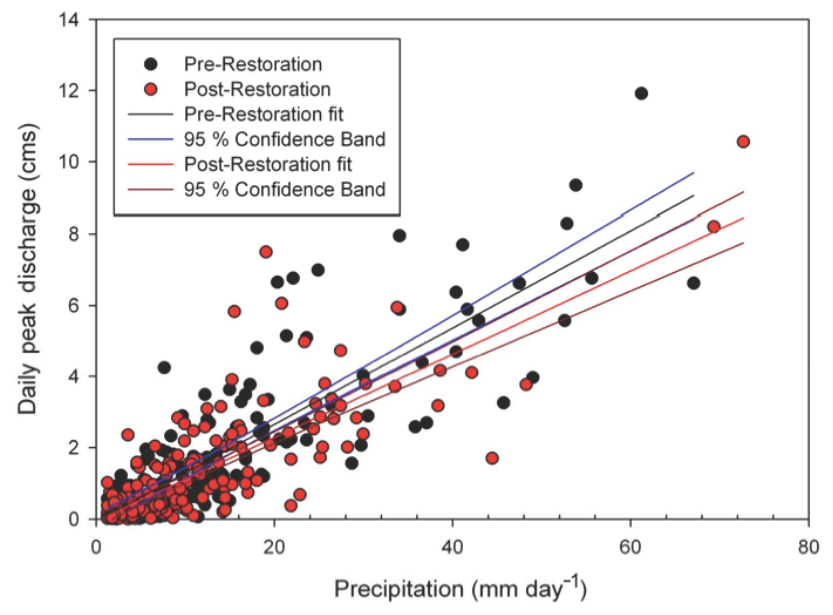

Figure 2. Effective precipitation and effective discharge for Minebank Run. Best-fit regression lines and $95 \%$ confidence lines included.

$(n=221)$. However, because there appears to be more of a skew to smaller storms in the pre-restoration period, of the largest 50 precipitation events, the median storm depth was $24.3 \mathrm{~mm}$ in the pre-restoration period ( $\left.n=50_{\text {largest }}\right)$ and $22.4 \mathrm{~mm}$ in the post-restoration period ( $n=50_{\text {largest }}$ ). Associated with the 50 largest precipitation events, the median storm peak discharge was $3.4 \mathrm{cms}$ in the pre-restoration pe- riod $\left(n=50_{\text {largest }}\right)$ and $2.5 \mathrm{cms}$ in the post-restoration period $\left(n=50_{\text {largest }}\right)$.

Regression lines and lines representing the $95 \%$ confidence bands were developed for both the pre-and postrestoration periods. The lower confidence band for the prerestoration data is nearly identical to the upper confidence band for the post-restoration data. The pre-restoration line has a slope of 0.136 with an $R^{2}$ of 0.74 (Eq. 5), whereas the post-restoration line has a slope of 0.117 with an $R^{2}$ of 0.67 (Eq. 6) (Fig. 2).

$$
\begin{aligned}
& \text { pre }-Q_{\text {peak }}=-0.073+0.136\left(\mathrm{PPT}_{\text {pre }}\right) \\
& \text { post }-Q_{\text {peak }}=-0.0596+0.117\left(\mathrm{PPT}_{\text {post }}\right)
\end{aligned}
$$

Comparison of the slopes and intercepts of the above equations using a general linear model found that the intercepts were not significantly different but the slopes were significantly different $(p=0.019)$. Therefore, the different slopes indicate that regression lines are different between the preand post-restoration effective precipitation - effective peak discharges relationship.

\subsection{Sources of water, carbon, and nitrogen exports among urban watersheds}

Routinely sampled stable deuterium $\left(\delta^{2} \mathrm{H}\right)$ and $\delta^{18} \mathrm{O}$ water isotopes were not significantly different between sites, including the restored stream, MBR $(p>0.05)$ (Table 2), and there was also no separation when plotting $\delta^{18} \mathrm{O}-\mathrm{H}_{2} \mathrm{O}$ vs. 

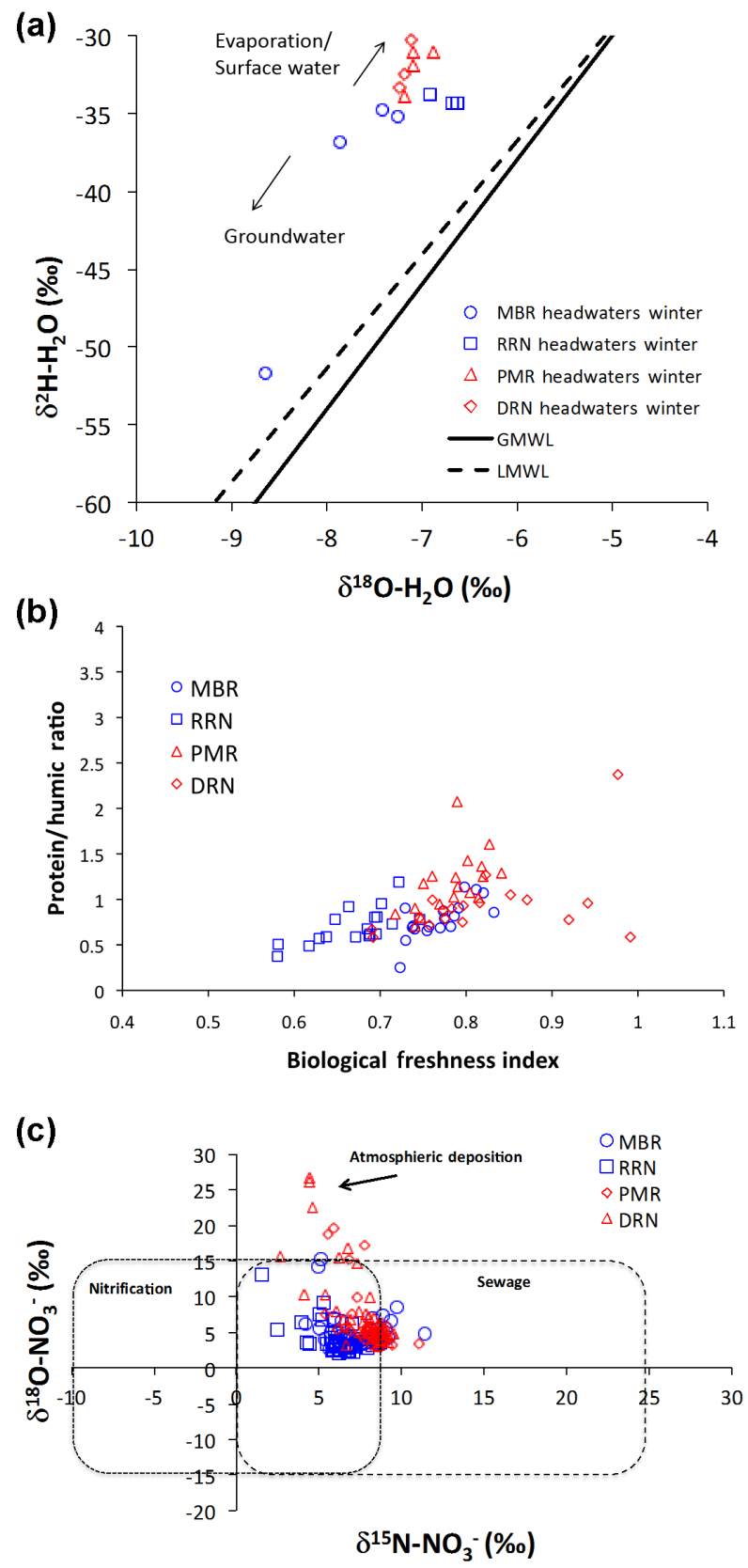

Figure 3. Comparison of (a) water isotopes $\left(\delta^{2} \mathrm{H}-\mathrm{H}_{2} \mathrm{O}\right.$ vs. $\delta^{18} \mathrm{O}-$ $\mathrm{H}_{2} \mathrm{O}$ ), (b) $\mathrm{C}$ quality metrics (biological freshness index vs. proteinto-humic ratio), and (c) nitrate isotopes $\left(\delta^{15} \mathrm{~N}-\mathrm{NO}_{3}^{-}\right.$vs. $\delta^{18} \mathrm{O}$ $\mathrm{NO}_{3}^{-}$). GMWL indicates global meteoric water line, LMWL indicates local meteoric water line (Craig, 1961; Kendall and Coplen, 2001).

$\delta^{2} \mathrm{H}-\mathrm{H}_{2} \mathrm{O}$ (Fig. S4a). Water isotope mixing model results also indicate no difference in the percent contribution of groundwater or rainwater sources to the stream between sites (Table 2). However, longitudinal data indicate that watersheds with higher \% ISC (PMR and DRN) had significantly higher $(p<0.05) \delta^{18} \mathrm{O}-\mathrm{H}_{2} \mathrm{O}$ isotope values in the headwaters than
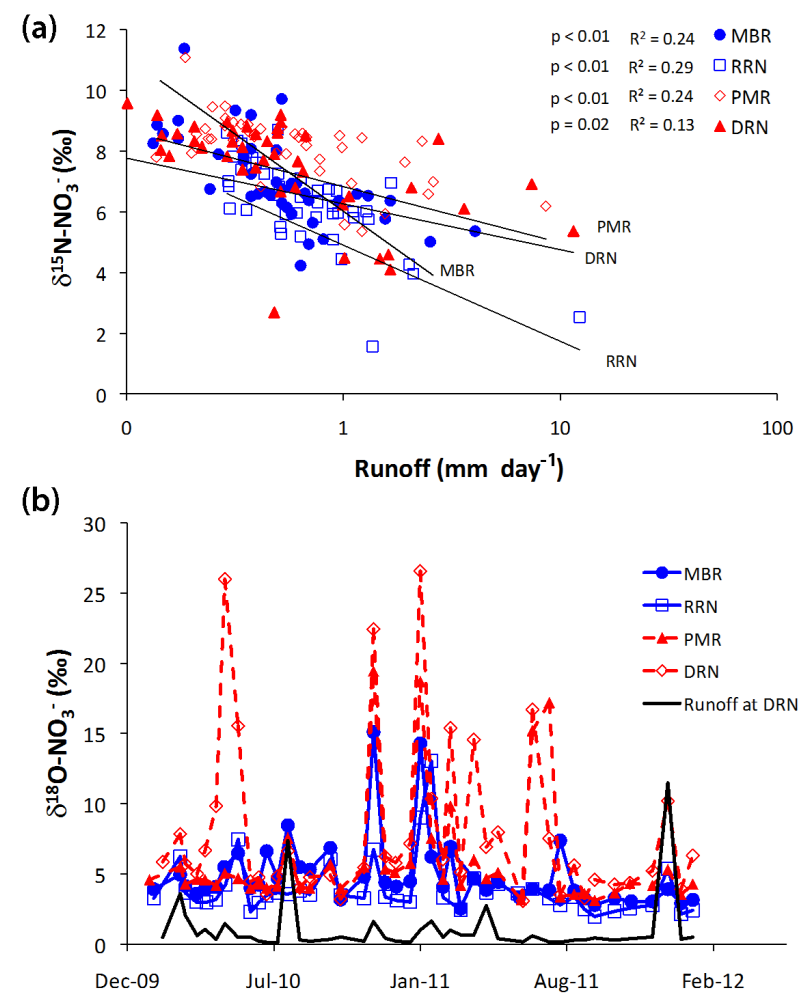

Figure 4. A comparison of (a) runoff vs. $\delta^{15} \mathrm{~N}_{-} \mathrm{NO}_{3}^{-}$and (b) runoff and $\delta^{18} \mathrm{O}-\mathrm{NO}_{3}^{-}$vs. time.

RRN and higher $\delta^{2} \mathrm{H}-\mathrm{H}_{2} \mathrm{O}$ isotopes ( $p=0.03$ for PMR \& $p=0.057$ for DRN) in the headwaters than MBR (Fig. 3a) during one winter sampling, indicative of greater evaporation of surface water at the more urban streams.

Fluorescence analyses indicated that the watersheds with greater \% ISC (PMR and DRN) transported more labile organic matter than the less urban site, RRN, as suggested by trends in the biological freshness index (BIX, $p<0.05)$ and protein-to-humic $(P / H)$ ratio $(p<0.05$, Fig. $3 b$, Table 2$)$, while MBR, the restored stream, was not different than the more urban sites (Fig. 3b, Table 2).

Only one of the more urban degraded streams (PMR) had greater $\delta^{15} \mathrm{~N}^{-\mathrm{NO}_{3}^{-}}$and contributions of $\mathrm{NO}_{3}^{-}$from wastewater than the restored stream (MBR) and the stream in the least developed watershed with SWM systems ( RRN, $p<0.05)$; the most urban stream (DRN) was not significantly different than the other streams (Fig. 3c, Table 2). The percent contribution of $\mathrm{NO}_{3}^{-}$from atmospheric sources, however, was greater in the watershed with the highest \% ISC (DRN) compared to the watershed with the lowest \% ISC (RRN) $(p<0.05$, Table 2$)$, but not different than the restored stream (MBR). Additionally, all sites showed a significant decline in $\delta^{15} \mathrm{~N}-\mathrm{NO}_{3}^{-}$with increasing runoff, and the two least urban sites (RRN and MBR), including the restored stream MBR, showed steeper slopes than PMR and DRN $(p<0.05$, 
Table 3. Annual runoff, $\mathrm{C}, \mathrm{N}$ and $\mathrm{P}$ exports (mean $\pm 95 \%$ confidence intervals) for the 2010, 2011, and 2012 calendar years.

\begin{tabular}{|c|c|c|c|c|c|}
\hline & Year & MBR & RRN & PMR & DRN \\
\hline \multicolumn{6}{|c|}{ Runoff (mm yr $\left.{ }^{-1}\right)$} \\
\hline & 2010 & $522 \pm 72$ & $325 \pm 23$ & $497 \pm 83$ & $625 \pm 117$ \\
\hline & 2011 & $647 \pm 88$ & $504 \pm 114$ & $639 \pm 110$ & $851 \pm 176$ \\
\hline & 2012 & $412 \pm 75$ & $382 \pm 61$ & $498 \pm 105$ & $564 \pm 164$ \\
\hline & MEAN & $527 \pm 45^{\mathrm{a}}$ & $404 \pm 44^{b}$ & $545 \pm 58^{\mathrm{ac}}$ & $680 \pm 89^{c}$ \\
\hline \multicolumn{6}{|c|}{ Carbon $\left(\mathrm{kg} \mathrm{ha}^{-1} \mathrm{yr}^{-1}\right)$} \\
\hline \multirow[t]{4}{*}{ DOC } & 2010 & $6.7 \pm 1.3$ & $6.2 \pm 0.8$ & $15 \pm 3$ & $28 \pm 7$ \\
\hline & 2011 & $9.1 \pm 1.6$ & $22 \pm 8$ & $27 \pm 5$ & $57 \pm 15$ \\
\hline & 2012 & $5.7 \pm 1.5$ & $11 \pm 3$ & $17 \pm 4$ & $33 \pm 12$ \\
\hline & MEAN & $7.2 \pm 1^{\mathrm{a}}$ & $13 \pm 3^{b}$ & $20 \pm 2^{c}$ & $39 \pm 7^{\mathrm{d}}$ \\
\hline \multirow[t]{4}{*}{ TOC } & 2010 & NA & NA & NA & NA \\
\hline & 2011 & $8.1 \pm 1.2$ & $26 \pm 11$ & $40 \pm 11$ & $45 \pm 11$ \\
\hline & 2012 & $5.1 \pm 1.1$ & $14 \pm 5$ & $26 \pm 9$ & $30 \pm 10$ \\
\hline & MEAN* & $6.6 \pm 0.5^{\mathrm{a}}$ & $20 \pm 4^{b}$ & $33 \pm 5^{c}$ & $38 \pm 5^{\mathrm{c}}$ \\
\hline \multicolumn{6}{|c|}{ Nitrogen $\left(\mathrm{kg} \mathrm{ha}^{-1} \mathrm{yr}^{-1}\right)$} \\
\hline \multirow[t]{4}{*}{$\mathrm{NO}_{3}^{-}$} & 2010 & $4.1 \pm 0.3$ & $3.7 \pm 0.2$ & $6.6 \pm 0.9$ & $4.1 \pm 0.6$ \\
\hline & 2011 & $4.6 \pm 0.4$ & $4.1 \pm 0.4$ & $8.0 \pm 1.1$ & $5.3 \pm 0.8$ \\
\hline & 2012 & $2.9 \pm 0.3$ & $3.7 \pm 0.2$ & $6.3 \pm 1.1$ & $3.6 \pm 0.7$ \\
\hline & MEAN & $3.9 \pm 0.2^{\mathrm{a}}$ & $3.8 \pm 0.2^{\mathrm{a}}$ & $7.0 \pm 0.6^{b}$ & $4.3 \pm 0.4^{\mathrm{a}}$ \\
\hline \multirow[t]{4}{*}{$\mathrm{TN}$} & 2010 & $4.8 \pm 0.4$ & $4.4 \pm 0.3$ & $9.1 \pm 1.5$ & $6.7 \pm 1.2$ \\
\hline & 2011 & $5.4 \pm 0.5$ & $5.4 \pm 0.7$ & $11.6 \pm 2.1$ & $8.8 \pm 1.6$ \\
\hline & 2012 & $3.4 \pm 0.5$ & $4.6 \pm 0.7$ & $9.1 \pm 2.1$ & $5.9 \pm 1.6$ \\
\hline & MEAN & $4.5 \pm 0.3^{\mathrm{a}}$ & $4.8 \pm 0.3^{\mathrm{a}}$ & $9.9 \pm 1.1^{\mathrm{b}}$ & $7.1 \pm 0.9^{\mathrm{c}}$ \\
\hline \multicolumn{6}{|c|}{ Phosphorus $\left(\mathrm{kg} \mathrm{ha}^{-1} \mathrm{yr}^{-1}\right)$} \\
\hline \multirow[t]{4}{*}{$\mathrm{PO}_{4}^{-3}$} & 2010 & $60 \pm 9$ & $58 \pm 6$ & $134 \pm 22$ & $167 \pm 37$ \\
\hline & 2011 & $75 \pm 11$ & $120 \pm 29$ & $172 \pm 30$ & $255 \pm 62$ \\
\hline & 2012 & $47 \pm 10$ & $66 \pm 11$ & $134 \pm 33$ & $122 \pm 40$ \\
\hline & MEAN & $61 \pm 6^{\mathrm{a}}$ & $81 \pm 11^{\mathrm{b}}$ & $147 \pm 17^{\mathrm{c}}$ & $181 \pm 28^{\mathrm{c}}$ \\
\hline \multirow[t]{4}{*}{ TP } & 2010 & $138 \pm 19$ & $160 \pm 17$ & $290 \pm 51$ & $330 \pm 60$ \\
\hline & 2011 & $202 \pm 29$ & $431 \pm 136$ & $379 \pm 72$ & $454 \pm 92$ \\
\hline & 2012 & $143 \pm 30$ & $314 \pm 89$ & $298 \pm 66$ & $306 \pm 76$ \\
\hline & MEAN & $161 \pm 15^{\mathrm{a}}$ & $302 \pm 54^{b}$ & $322 \pm 37^{\mathrm{b}}$ & $363 \pm 45^{b}$ \\
\hline \multicolumn{6}{|c|}{ Wastewater indicator anions $\left(\mathrm{g} \mathrm{ha}^{-1} \mathrm{yr}^{-1}\right)$} \\
\hline \multirow[t]{4}{*}{$\mathrm{F}^{-}$} & 2010 & $230 \pm 11$ & b.d. & $2.1 \times^{4} \pm 1.0 \times \times^{4}$ & $726 \pm 87$ \\
\hline & 2011 & $235 \pm 10$ & b.d. & $1.8 \times \times^{4} \pm 5.5 \times^{3}$ & $606 \pm 91$ \\
\hline & 2012 & $67 \pm 5$ & b.d. & $5.4 \times^{3} \pm 3.5 \times^{3}$ & $281 \pm 45$ \\
\hline & MEAN & $177 \pm 5^{\mathrm{a}}$ & NA & $1.5 \times{ }^{4} \pm 4.0 \times 3 b$ & $583 \pm 45^{\mathrm{c}}$ \\
\hline \multirow[t]{4}{*}{$\mathrm{I}^{-}$} & 2010 & $19 \pm 1$ & $21 \pm 1$ & $20 \pm 2$ & $50 \pm 7$ \\
\hline & 2011 & $29 \pm 2$ & $41 \pm 8$ & $39 \pm 4$ & $85 \pm 13$ \\
\hline & 2012 & $16 \pm 1$ & $24 \pm 4$ & $22 \pm 2$ & $46 \pm 8$ \\
\hline & MEAN & $21 \pm 1^{\mathrm{a}}$ & $29 \pm 3^{b}$ & $27 \pm 2^{b}$ & $60 \pm 6^{c}$ \\
\hline
\end{tabular}

MBR indicates Minebank Run, RRN indicates Red Run, PMR indicates Powder Mill Run, DRN indicates Dead Run. Different letters $\left({ }^{\mathrm{a}},{ }^{\mathrm{b}},{ }^{\mathrm{c}}\right.$, or $\left.{ }^{\mathrm{d}}\right)$ indicate significant differences, based on $95 \%$ CI of exports. DOC indicates dissolved organic C; TOC indicates total organic C; TN indicates total nitrogen; TP indicates total phosphorus; b.d. indicates values below detection. * Note that this range is from 2011-2012, unlike the others. 

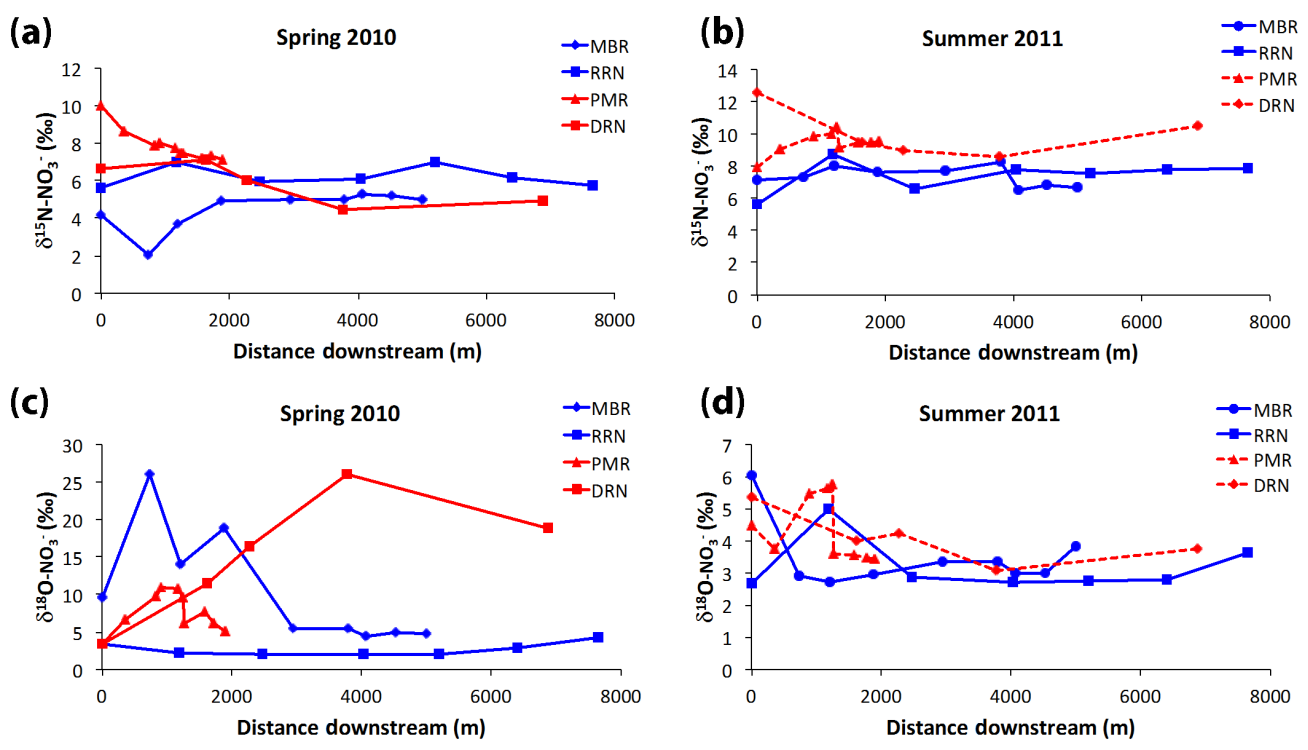

Figure 5. Longitudinal patterns in $\delta^{15} \mathrm{~N}-\mathrm{NO}_{3}^{-}$and $\delta^{18} \mathrm{O}-\mathrm{NO}_{3}^{-}$during spring (a, c) and summer (b, d) seasons.

Fig. 4a). Also, the more urban sites (PMR and DRN) showed pulses in $\delta^{18}{\mathrm{O}-\mathrm{NO}_{3}^{-}}^{-}$during rain events (Fig. $4 \mathrm{~b}$ ), which suggests that atmospheric $\mathrm{NO}_{3}^{-}$contributions can increase with runoff.

Longitudinally, after a spring rain event, the wastewater nitrate signal (based on $\delta^{15} \mathrm{~N}-\mathrm{NO}_{3}^{-}$values) declines from the headwater to the mouth in the more urban watershed (DRN), while the $\delta^{15} \mathrm{~N}^{-\mathrm{NO}_{3}^{-}}$values are relatively constant at the restored stream, MBR, and least urban watershed, RRN (Fig. 5a). Conversely, during summer baseflow, the $\delta^{15} \mathrm{~N}$ $\mathrm{NO}_{3}^{-}$values are relatively steady at all four sites, but with the more urban streams (PMR and DRN) having consistently higher $\delta^{15} \mathrm{~N}^{-N^{-}} \mathrm{O}_{3}^{-}$values (Fig. 5b). The contribution of atmospheric nitrate (based on $\delta^{18} \mathrm{O}-\mathrm{NO}_{3}^{-}$values) during the spring high flow period generally increased downstream for the more urban degraded streams, but decreased for the restored stream, MBR, and stayed the same longitudinally for the less urban watershed with SWM systems (RRN, Fig. 5c). There was little difference in the $\delta^{18} \mathrm{O}-\mathrm{NO}_{3}^{-}$values longitudinally for summer (Fig. 5d).

\subsection{Carbon, nutrient, and anion exports among urban watersheds}

Among watersheds, annual DOC export showed up to a 5fold difference and there was up to a 2-fold difference in annual TP exports. The most urban watershed, DRN, exhibited the highest and the restored stream, MBR, exhibited the lowest annual TOC and TP exports (Table 3, $p<0.05$ for DRN vs. MBR). The restored stream and the least urban stream draining a watershed with SWM systems, RRN, also exhibited lower annual total $\mathrm{N}(\mathrm{TN})$ exports compared to the more urban catchments (DRN and PMR) ( $p<0.05$, Table 3). Annual $\mathrm{NO}_{3}^{-}$exports were not significantly different between the restored stream and the most urban degraded stream, DRN (Table 3). Annual exports of wastewater indicator anions (fluoride and iodide) showed up to 3-fold differences among watersheds, with DRN exhibiting the highest and the restored stream, MBR, the lowest annual exports (Table 3, $p<0.05$ for DRN vs. MBR).

\subsection{Flashiness of water, carbon, and nutrient exports among urban watersheds}

The sites with greater \% ISC (PMR and DRN) had significantly higher monthly peak runoff, mean coefficient of variation of peak runoff, and flashiness index ( $p<0.05$, Table 4 , Fig. 6a) than RRN and the restored stream MBR. RRN (the site with lowest \% ISC) also had lower frequency of peak flow runoff events above $3 \times$ median monthly runoff, and longer hydrograph duration than the other sites (Table 4). Hydrologic lag time was not significantly different among sites (Table 4).

The two most urban streams (PMR and DRN) showed more variable and pulsed runoff and exports, based on the the flashiness index (Fig. 6) and the time series of daily exports for C, N, and P (Fig. 7). Typically, exports of C, N, $\mathrm{P}$, and wastewater indicator anions $\left(\mathrm{F}^{-}\right.$and $\left.\mathrm{I}^{-}\right)$, showed a lower flashiness index (less variable or pulsed) for sites with lower \% ISC including the restored stream (MBR and RRN; Fig. 6b-d). Based on nutrient duration curves, the urban degraded sites with higher \% ISC (PMR and DRN) exported more $\mathrm{C}, \mathrm{N}$, and $\mathrm{P}$ during higher flows, while the restored stream MBR and the less urban sites with SWM systems 
Table 4. Hydrologic flashiness metrics (mean $\pm \mathrm{SE}$ ).

\begin{tabular}{lrrrccccc}
\hline & $\begin{array}{c}\text { Watershed } \\
\text { area }\left(\mathrm{km}^{2}\right)\end{array}$ & $\begin{array}{c}\% \\
\text { ISC }\end{array}$ & $\begin{array}{c}\text { Mean peak } \\
\text { flow runoff } \\
\left(\text { mm day }^{-1}\right)\end{array}$ & $\begin{array}{c}\text { Monthly CV (\%) } \\
\text { of peak runoff }\end{array}$ & $\begin{array}{c}\text { Freq. peaks } \\
\text { per month }>3 \times \\
\text { monthly median } Q\end{array}$ & $\begin{array}{c}\text { Mean } \\
\text { hydrograph } \\
\text { duration (h) }\end{array}$ & $\begin{array}{c}\text { Mean Lag } \\
\text { time (h) }\end{array}$ & $\begin{array}{c}\text { Avg. } \\
\text { monthly } \\
\text { flash index }\end{array}$ \\
\hline MBR & 5.3 & 21.9 & $9.4 \pm 1.0^{\mathrm{a}}$ & $92 \pm 6^{\mathrm{ab}}$ & $5.7 \pm 0.4^{a c}$ & $40 \pm 1.7^{\mathrm{a}}$ & $4.7 \pm 0.3^{\mathrm{a}}$ & $0.9 \pm 0.1^{\mathrm{a}}$ \\
RRN & 19.1 & 14.6 & $13.2 \pm 1.9^{\mathrm{b}}$ & $63 \pm 8^{\mathrm{b}}$ & $2.2 \pm 0.3^{\mathrm{b}}$ & $64 \pm 2.4^{\mathrm{b}}$ & $4^{\mathrm{b}} \pm .5 \pm 0.4^{\mathrm{a}}$ & $0.5 \pm 0.0^{\mathrm{b}}$ \\
PMR & 9.4 & 35.5 & $55.4 \pm 5.8^{\mathrm{c}}$ & $104 \pm 7^{\mathrm{a}}$ & $5.3 \pm 0.5^{\mathrm{a}}$ & $30 \pm 1.4^{\mathrm{c}}$ & $5.1 \pm 0.3^{\mathrm{a}}$ & $1.0 \pm 0.1^{\mathrm{a}}$ \\
DRN & 14.3 & 39.3 & $44.9 \pm 4.5^{\mathrm{c}}$ & $116 \pm 7^{\mathrm{a}}$ & $7.0 \pm 0.5^{\mathrm{c}}$ & $50 \pm 1.5^{\mathrm{d}}$ & $4.7 \pm 0.2^{\mathrm{a}}$ & $1.2 \pm 0.1^{\mathrm{c}}$ \\
\hline
\end{tabular}

MBR indicates Minebank Run, RRN indicates Red Run, PMR indicates Powder Mill Run, DRN indicates Dead Run. Different letters ( ${ }^{a}$, b ${ }^{c}$, or ${ }^{d}$ ) indicate significant differences $(p<0.05)$ based on pairwise comparisons of 3 years of mean monthly flashiness metrics. ISC indicates impervious surface cover; CV indicates coefficient of variation; $Q$ indicates discharge; Lag time indicates time between rainfall centroid and peak runoff; flash index indicates average daily change in mean daily streamflow per month, divided by the mean monthly flow.

(a)

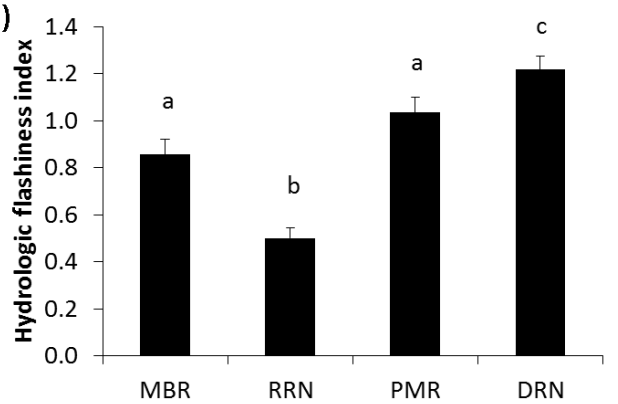

(c)

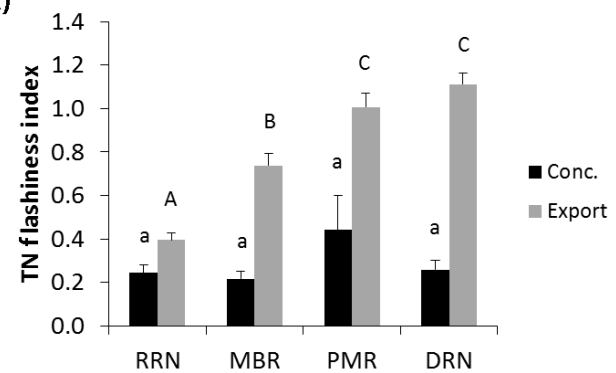

(b)

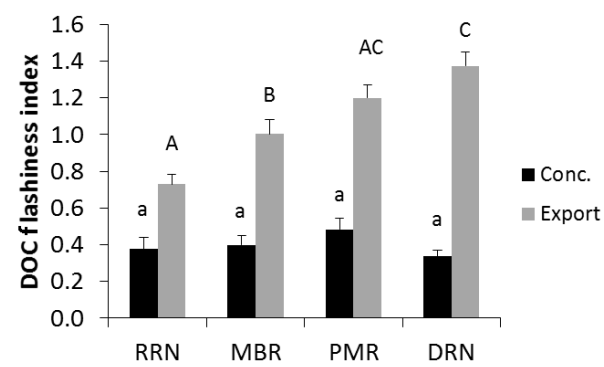

(d)

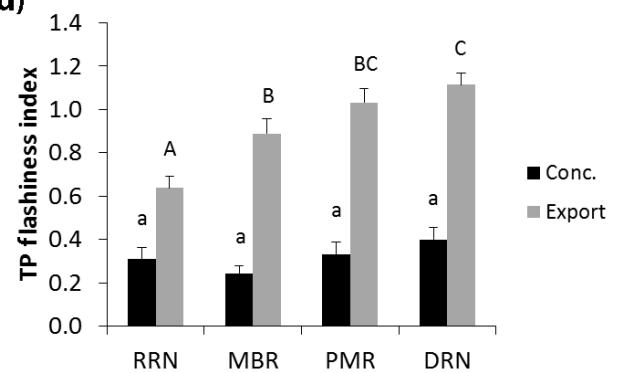

Figure 6. Comparison of the flashiness index for (a) runoff, (b) dissolved organic carbon (DOC) concentration and export, (c) total nitrogen (TN) concentration and export, and (d) total phosphorus (TP) concentration and export. Conc. indicates concentration. Error bars are standard errors of the mean. $\mathrm{N}=36$, from averaging the monthly flashiness index over 3 years. Flashiness index indicates average change in daily export or routinely sampled concentration per month, divided by the mean monthly export or concentration per month.

(RRN) exported more during lower flows (Fig. 8). Similarly, the $\mathrm{F} 75$ metric showed that $75 \%$ of $\mathrm{NO}_{3}^{-}, \mathrm{TN}, \mathrm{PO}_{4}^{-3}, \mathrm{~F}^{-}$, and $\mathrm{I}^{-}$export occurred for the site with restoration (MBR) and with lower \% ISC and more SWM (RRN) typically at lower runoff than in higher \% ISC sites PMR and DRN (Table 5).

\section{Discussion}

Our results show that watershed urbanization increases hydrologic flashiness and pulses in exports of carbon, nutrients, and atmospheric nitrate sources. From a management perspective, our results suggest that combining stream restoration with sewer infrastructure restoration has the potential to minimize sources, fluxes, and flowpaths of nutrients. Overall, impervious surface cover appeared to be an important indicator of timing of fluxes from the watersheds. Watersheds with older sewer infrastructure and higher ISC (DRN and PMR) showed significant differences in $\mathrm{NO}_{3}^{-}$sources and $\mathrm{C}, \mathrm{N}$, and $\mathrm{P}$ exports than the stream restoration site (MBR) and the less urban stream with SWM systems in its catchment (RRN). Below, we discuss potential effects of stream restoration and sewer infrastructure on sources, fluxes, and flowpaths of nutrients across a broader range of sites and urban development.

\subsection{Pre-restoration and post-restoration hydrologic analysis}

Restoration had subtle but statistically significant impacts on hydrology by decreasing peak discharges during storm 

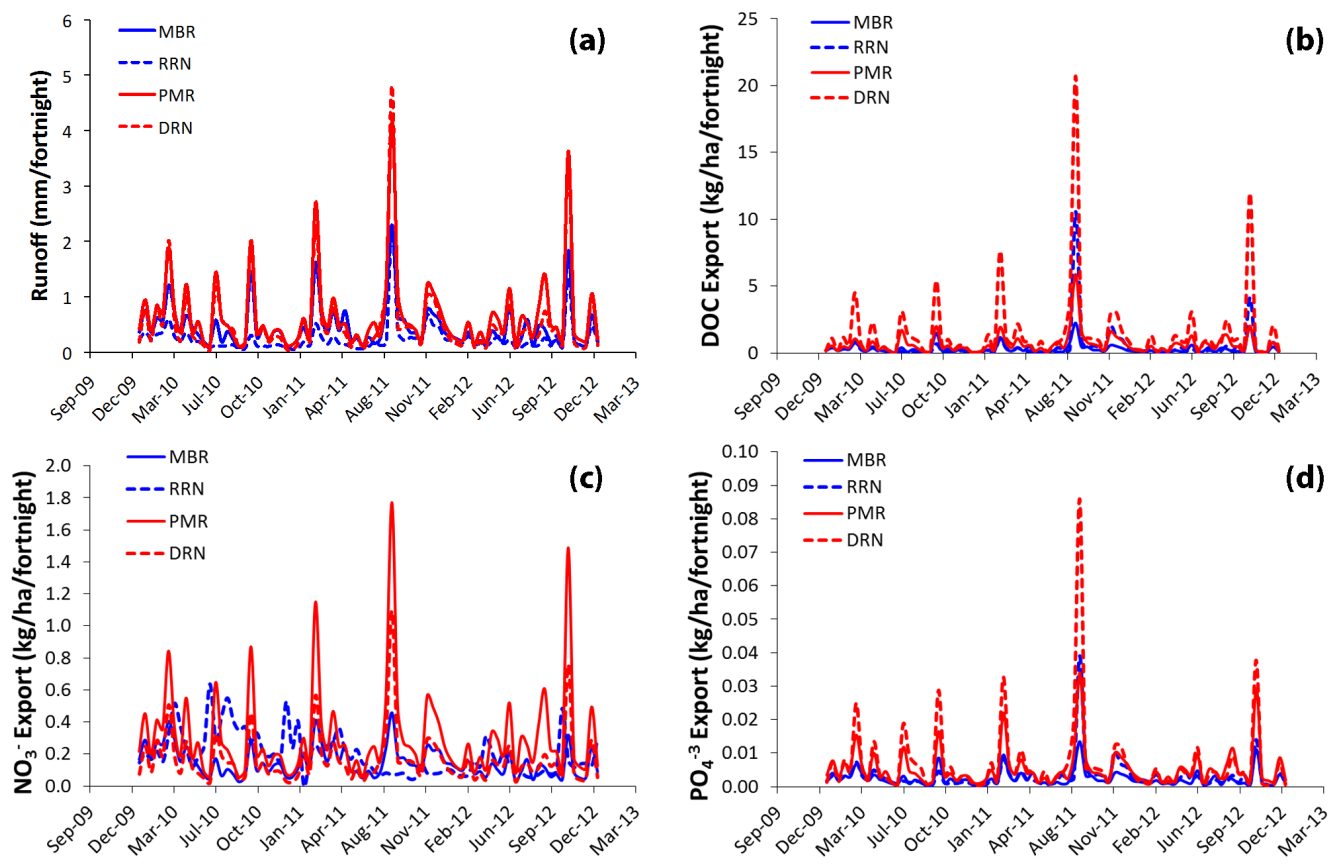

Figure 7. Routinely sampled (a) runoff, (b) DOC export, (c) $\mathrm{NO}_{3}^{-}$export, and (d) $\mathrm{PO}_{4}^{-3}$ export over time.

Table 5. F75 metric: the runoff below which $75 \%$ of nutrients are exported.

\begin{tabular}{|c|c|c|c|c|c|c|c|c|}
\hline Site & $\begin{array}{r}\mathrm{F} 75 \\
\mathrm{DOC} \\
\left(\mathrm{mm} \mathrm{day}^{-1}\right)\end{array}$ & $\begin{array}{r}\mathrm{F} 75 \\
\mathrm{TOC} \\
\left(\mathrm{mm} \mathrm{day}^{-1}\right)\end{array}$ & $\begin{array}{r}\mathrm{F} 75 \\
\mathrm{NO}_{3}^{-} \\
\left(\mathrm{mm} \mathrm{day}^{-1}\right)\end{array}$ & $\begin{array}{r}\mathrm{F} 75 \\
\mathrm{TN} \\
\left(\mathrm{mm} \mathrm{day}^{-1}\right)\end{array}$ & $\begin{array}{r}\mathrm{F} 75 \\
\mathrm{PO}_{4}^{-3} \\
\left(\mathrm{~mm} \mathrm{day}^{-1}\right)\end{array}$ & $\begin{array}{r}\mathrm{F} 75 \\
\mathrm{TP} \\
\left(\mathrm{mm} \mathrm{day}^{-1}\right)\end{array}$ & $\begin{array}{r}\mathrm{F} 75 \\
\mathrm{I}^{-} \\
\left(\mathrm{mm} \mathrm{day}^{-1}\right)\end{array}$ & $\begin{array}{r}\mathrm{F} 75 \\
\mathrm{~F}^{-} \\
\left(\mathrm{mm} \mathrm{day}^{-1}\right)\end{array}$ \\
\hline MBR & 16.1 & 15.1 & 6.9 & 7.3 & 12.4 & 12.4 & 4.6 & 2.8 \\
\hline RRN & 34.1 & 44.5 & 2.2 & 3.1 & 11.7 & 23.7 & 7.1 & NA \\
\hline PMR & 22.8 & 38.1 & 14.0 & 20.5 & 20.8 & 20.8 & 8.6 & 34.0 \\
\hline DRN & 57.3 & 37.4 & 25.9 & 28.3 & 39.3 & 29.8 & 17.9 & 16.5 \\
\hline
\end{tabular}

MBR indicates Minebank Run, RRN indicates Red Run, PMR indicates Powder Mill Run, DRN indicates Dead Run. DOC indicates dissolved organic C; TOC indicates total organic C; TN indicates total nitrogen; TP indicates total phosphorus. Similar to Shields et al. (2008).

events in this flashy system. Stream restoration, which involved reconnection of the floodplain, was likely able to reduce peak discharge by increasing infiltration when bankfull discharge overflows onto the floodplain during storm events (Bohnke et al., 2002; Cendon et al., 2010; Hester and Gooseff, 2010). In urban settings, imperious surfaces are identified as the primary mechanism for flashy hydrology and stream channel degradation (Doheny et al., 2006; Leopold, 1968; Paul and Meyer, 2001; Walsh et al., 2005b). As a result, small increases in impervious surface cover elicit disproportionately large reductions in water quality and biotic integrity (Brabec et al., 2002). Therefore, even small reductions in hydrologic flashiness may be an important benefit of restoration.

The Ppt- $Q_{\mathrm{pk}}$ regression method for urban stream analysis used readily available data sources that are potentially applicable where there have been management changes but typical rainfall-runoff metrics do not apply (i.e., curve numbers).
A clear understanding of statistically significant effects (i.e., decreased peak discharges) due to restoration are necessary to support decisions to enhance restoration beyond simple channel reconfigurations and make more active use of floodplains and/or synergistically integrating stormwater management in the uplands. The proposed Ppt- $Q_{\mathrm{pk}}$ approach, however, does not quantify change, but only indicates if a change in the peak discharge has occurred. Also, this regression method may not be applicable to larger basins which have different routing pathways and processes that may not occur at the same rate as in a smaller basin (Ziemer and Lisle, 1998). Further study is needed to comprehensively evaluate the effects of stream restoration on hydrologic responses in larger basins and different climates. The wide availability of high-resolution precipitation data and discharge data make this a potentially useful method to evaluate management effects. 

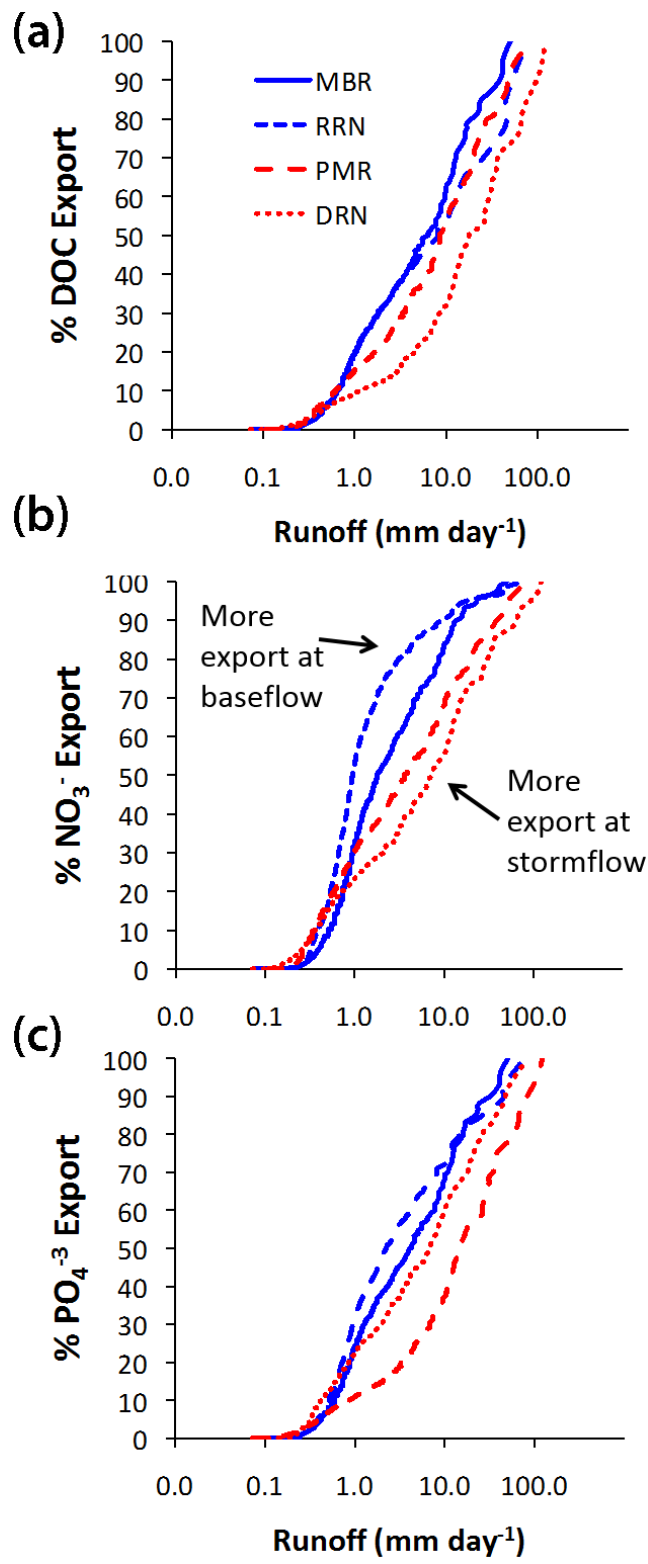

Figure 8. Nutrient duration curves for (a) DOC, (b) $\mathrm{NO}_{3}^{-}$, and (c) $\mathrm{PO}_{4}^{-3}$ daily export.

\subsection{Sources of water, carbon, and nitrogen exports among urban watersheds}

All four watersheds showed no significant differences in water isotope signatures, potentially due to complex mixing of surface water with groundwater and leaky urban water infrastructure, which is common among urban watersheds of the Baltimore LTER site (Kaushal and Belt, 2012; Kaushal et al., 2014a; Newcomer et al., 2014). Previous work has suggested that urban watersheds receive considerable inputs of water from a combination of groundwater and leaky urban water infrastructure (Bhaskar and Welty, 2012; Kaushal and Belt, 2012; Kaushal et al., 2014a). Recent evidence suggests that the urban stream corridor can be an important nonpoint source (or sink) of some pollutants due to leaky sewer infrastructure, groundwater contributions, and also instream production of labile organic carbon (Divers et al., 2013; Kaushal et al., 2014a; Newcomer et al., 2014). In fact, City of Baltimore has detailed records for the dates and locations of sewer overflows through their open data website (https://data.baltimorecity.gov/) and these sewer overflows have occurred within the watersheds of this study.

The more urbanized watersheds (PMR and DRN), as well as the restored stream, MBR, contained more labile dissolved organic matter than the more recently developed and less urban watershed with SWM systems (RRN). From studies throughout the globe, it is known that protein-like and more bioavailable or labile organic matter is typically associated with wastewater carbon sources (Baker, 2001; Goldman et al., 2012; Li et al., 2015; Yu et al., 2015). As a result, the higher BIX, $P / H$ ratio, and protein-like organic matter in the restored stream MBR, as well as the more urban watersheds (PMR and DRN), is likely due to leaky sewers typically found in older urban watersheds (Hudson et al., 2008; Kaushal et al., 2011). The watersheds in this study are not influenced by combined sewer overflows or typical point source discharges of wastewater. However, the more labile organic matter found in the more urban streams may also be due to lack of a riparian zone, and more light availability, typical of degraded urban streams (Goetz et al., 2003), which promotes autotrophic growth and more biologically labile DOM (Huguet et al., 2009; McKnight et al., 2001; Pennino et al., 2014; Petrone et al., 2011). DOM derived from autochthonous production also tends to be more labile than DOC derived from terrestrial organic matter leaching, which is usually more recalcitrant and humified (Huguet et al., 2009; McKnight et al., 2001; Petrone et al., 2011). Consequently, the elevated humification index in the less urban watershed, RRN, with watershed-level SWM systems could have resulted from increased allochthonous inputs of recalcitrant terrestrial organic matter (Duan et al., 2014).

Differences in $\mathrm{NO}_{3}^{-}$sources among urban watersheds likely result from differences in the age of development and extent of \% ISC and less likely due to restoration or management. High $\delta^{15} \mathrm{~N}^{-\mathrm{NO}_{3}^{-}}$isotope levels are indicative of nitrate from wastewater sources (Divers et al., 2014; Kaushal et al., 2011). $\mathrm{NO}_{3}^{-}$from wastewater was highest in one of the more urban sites (PMR), and because there are no point sources for wastewater in the streams of this study, this indicates greater $\mathrm{NO}_{3}^{-}$contributions from leaky sanitary sewers at this site (Divers et al., 2014; Kaushal et al., 2011); yet all sites showed wastewater as the greatest source of $\mathrm{NO}_{3}^{-}$. Due to stream restoration at MBR, the neighboring sewer pipes were repaired and stabilized (Doheny et al., 2006; Mayer et al., 2010; US EPA, 2009), likely resulting in less sewer leaks at Minebank Run longitudinally along the restored reach compared to the more urban streams (DRN and PMR). Nonethe- 
less, during summer baseflow, the $\delta^{15} \mathrm{~N}^{-\mathrm{NO}_{3}^{-}}$isotope levels were consistently high along each stream length, suggesting the influence of leaky sewer inputs through groundwater recharge (Divers et al., 2014; Hall et al., 2016); but during the rainier spring season, the more urban streams (DRN and PMR) showed a decline in $\delta^{15} \mathrm{~N}^{-\mathrm{NO}_{3}^{-}}$isotope levels, indicating possible dilution of sewer-sourced nitrate from rainwater entering from connected impervious surfaces (Divers et al., 2014). This dilution of wastewater $\mathrm{NO}_{3}^{-}$was not observed at the other sites, potentially due to less connected impervious surfaces at the least urban watershed (RRN) and the reduction of peak discharge due to the reconnected floodplain for the restored stream (MBR) (Bohnke et al., 2002; Boyer and Kieser, 2012; Cendon et al., 2010; Hester and Gooseff, 2010; Poff et al., 2006b). Nitrification was the second highest source for $\mathrm{NO}_{3}^{-}$at all sites, and likely contributed more $\mathrm{NO}_{3}^{-}$in the restored stream (MBR) and the least urban stream with watershed-level SWM systems (RRN) compared to the more urban streams (DRN and PMR), due to less labile carbon (Strauss and Lamberti, 2002) and possibly due to higher sediment $\mathrm{C}$ content at these sites (Arango and Tank, 2008). The greater atmospheric $\mathrm{NO}_{3}^{-}$during high flows in PMR and DRN is a result of the higher impervious surface cover at these sites, allowing for the more direct connection of rainfall to the stream corridor (Buda and DeWalle, 2009; Burns et al., 2009; Silva et al., 2002). Furthermore, the inverse relationship between $\delta^{15} \mathrm{~N}_{-} \mathrm{NO}_{3}^{-}$and $\delta^{18} \mathrm{O}-\mathrm{NO}_{3}^{-}$at all sites indicated mixing of sewage and atmospheric $\mathrm{NO}_{3}^{-}$ to varying degrees among these urban watersheds (Kaushal et al., 2011). The downstream increase in $\delta^{18} \mathrm{O}-\mathrm{NO}_{3}^{-}$after a spring rain event shows how the more urban streams maintain atmospheric $\mathrm{NO}_{3}^{-}$throughout their stream length. The restored stream only showed atmospheric sourced $\mathrm{NO}_{3}^{-}$in its headwaters (which is more developed) but not further downstream. The least urban watershed with SWM systems, RRN, showed minimal or no atmospheric $\mathrm{NO}_{3}^{-}$signal throughout its entire stream length, corresponding with it having no directly connected ISC. Conversely, during summer baseflow, there were no differences in the atmospheric $\mathrm{NO}_{3}^{-}$signal along the stream length for all four watersheds. These results suggest the dynamic potential of urban streams to transform nitrate along the broader urban watershed continuum based on gradients in land use and infrastructure (Kaushal et al., 2014a).

\subsection{Variability in carbon and nutrient exports among urban watersheds}

The higher $\mathrm{C}$ exports in the urban watersheds with greater $\%$ ISC compared to the restored stream and the least urban watershed with SWM systems may be due to increased autochthonous $\mathrm{C}$ production (described above) and greater leaky sanitary sewers (Kaushal and Belt, 2012). Inputs of leaves and other organic materials from street trees and organic matter delivered by storm drains from impervious sur- faces likely also contributed to higher $\mathrm{C}$ exports in the urban degraded watersheds (Kaushal and Belt, 2012). Differences may have also stemmed from altered in-stream processing and elevated gross primary production in more urbanized, degraded streams (Kaushal et al., 2014a). The restored stream also likely had lower $\mathrm{C}$ exports due to increased ability to retain and process carbon in transient storage zones, like pools, through hyporheic exchange, or in the reconnected floodplain (Bukaveckas, 2007; Groffman et al., 2005; Klocker et al., 2009; Mulholland et al., 1997; Pennino et al., 2014), whereas degraded urban streams that are highly eroded can have less transient storage areas to potentially store and process carbon (Kurth et al., 2015; Sudduth et al., 2011a). Previous work at nearby sites suggests that labile $\mathrm{C}$ export from urban watersheds has the potential to increase oxygen demand, alkalinity, and denitrification (Kaushal et al., 2014a; Newcomer et al., 2012). Relatively less work has quantified exports of organic $\mathrm{C}$ from urban watersheds (Bullock et al., 2011; Worrall et al., 2012). The $C$ exports of the urban watersheds in the present study, ranging from 6 to $57 \mathrm{~kg} \mathrm{ha}^{-1} \mathrm{yr}^{-1}$, were within the range or higher than nearby forested watersheds in North America and elsewhere, which range from 10 to $100 \mathrm{~kg} \mathrm{ha}^{-1} \mathrm{yr}^{-1}$ (e.g., Aitkenhead-Peterson et al., 2005; Dillon and Molot, 1997; Hope et al., 1994; Mulholland and Kuenzler, 1979; Tate and Meyer, 1983).

The TN exports in this study, which ranged from 3 to $8 \mathrm{~kg} \mathrm{ha}^{-1} \mathrm{yr}^{-1}$, were generally equal to or higher than most urbanized watersheds, which range from 0.2 to $9 \mathrm{~kg} \mathrm{ha}^{-1} \mathrm{yr}^{-1}$ (Lewis and Grimm, 2007; Petrone, 2010; Sobota et al., 2009), though some urban watersheds can export TN as high as $30 \mathrm{~kg} \mathrm{ha}^{-1} \mathrm{yr}^{-1}$ (e.g., Line et al., 2002). TN exports in this study were also similar to the exports estimated in some of the same urban watersheds at the Baltimore LTER site during similar annual runoff (Kaushal et al., 2008a; Shields et al., 2008). Previous work has shown that annual runoff is a strong predictor of annual $\mathrm{N}$ exports in the Baltimore LTER watersheds (Kaushal et al., 2011; Kaushal et al., 2008a), and the relationship between runoff and $\mathrm{N}$ export rate varies significantly across a broad range of sites based on the degree of watershed urbanization (Kaushal et al., 2014b). The higher TN exports in the more urban sites (PMR and DRN) compared to the restored stream (MBR) may be due to various reasons, such as greater $\mathrm{N}$ inputs from leaky sewers in the more urban and older watersheds and/or greater $\mathrm{N}$ removal through denitrification in the restored stream due its hydrologically connected floodplains (Kaushal et al., 2008b; Klocker et al., 2009), alluvial wetlands, and greater hyporheic exchange (Bukaveckas, 2007; Harrison et al., 2011; Kaushal et al., 2008b; Roley et al., 2012). In fact, the stream restoration at MBR involved bank stabilization and some repairs of sewer pipes (Doheny et al., 2006; Mayer et al., 2010; US EPA, 2009) and consequently may have reduced sewer leaks, but detailed research is needed to evaluate the effects of sewer repairs on watershed $\mathrm{N}$ inputs. There were also higher peak flows and a greater proportion of nu- 
trient exports at higher flows, as indicated by the F75 metric for the more urban sites (PMR and DRN), similar to previous work (e.g., Horowitz, 2009; Shields et al., 2008). The lower proportion of $\mathrm{N}$ exports during higher flows for the restored stream (MBR) may be due to the connected floodplain attenuating higher flows (Bohnke et al., 2002; Cendon et al., 2010; Hester and Gooseff, 2010), as evidenced by the effective discharge results described above and due to less connected impervious cover (Poff et al., 2006b; Smith et al., 2013). The lower TN exports in the watershed with SWM systems (RRN) may be due to an extensive undeveloped riparian buffer (Mayer et al., 2007) and from its SWM systems in the watershed (Bettez and Groffman, 2012), which both can enhance $\mathrm{N}$ removal.

Relatively fewer studies of $\mathrm{P}$ exports in urban watersheds exist compared to those addressing $\mathrm{N}$ exports (Duan et al., 2012; Petrone, 2010). P exports from the present study, which ranged from 0.14 to $0.54 \mathrm{~kg} \mathrm{ha}^{-1} \mathrm{yr}^{-1}$, were similar to those reported elsewhere (e.g., Petrone, 2010). Though prior to improvements in wastewater treatment, urban watersheds impacted by sewage treatment plans were previously reported to export $\mathrm{P}$ ranging from 0.027 to $2.11 \mathrm{~kg} \mathrm{ha}^{-1} \mathrm{yr}^{-1}$ (Hill, 1981). Watershed $\mathrm{P}$ exports were also within the range reported by Duan et al. (2012) for Baltimore LTER watersheds, where the less urban, more managed watersheds typically showed lower TP and soluble reactive phosphorus exports. The higher exports of TP and $\mathrm{PO}_{4}^{-3}$ at the more urban watersheds (PMR and DRN) may indicate greater inputs from leaky sewers and possibly from erosion of the stream channel (personal observations) due to flashier hydrology at these sites (Paul and Meyer, 2001). The lower TP exports in the restored stream may be due to increased hyporheic exchange and floodplain connection, which have been shown to increase P retention (Butturini and Sabater, 1999; Mulholland et al., 1997). Higher $\mathrm{F}^{-}$and $\mathrm{I}^{-}$concentrations and exports in the older, more urban, and less managed sites further suggest that there are water inputs from leaky drinking water pipes and sewers (Darcan et al., 2005; Gehr and Leduc, 1992; $\mathrm{Xu}$ et al., 2016). More work is necessary to track sources of $\mathrm{P}$ in urban watersheds.

\subsection{Flashiness of water, carbon, and nutrient exports among urban watersheds}

As expected, the streams with greater \% ISC (PMR and DRN) showed more flashy hydrology and evidence that overland flow or storm drain inputs were a significant flowpath (as supported by the water and nitrate isotope mixing model results). In-stream restoration features of MBR may have contributed somewhat to dampening flood pulses by promoting floodplain reconnection (Bohnke et al., 2002; Cendon et al., 2010; Hester and Gooseff, 2010). However, the inconsistently lower hydrologic flashiness metrics for MBR compared to the more urban streams (PMR and DRN) may indicate stream restoration has variable hydrologic impact (e.g.,
Emerson et al., 2005; Sudduth et al., 2011b) depending on the storm size or specific features of the stormwater management. At RRN, the lower \% ISC, higher \% SWM, and larger watershed size likely contributed to reduced hydrologic flashiness by disconnecting impervious surfaces and promoting infiltration (Meierdiercks et al., 2010, Baltimore County, Maryland Department of Environmental Protection and Sustainability).

The significantly more pulsed $\mathrm{C}$ and nutrient exports in the more urban watersheds (PMR and DRN) can be attributed to hydrologic variability and impervious surface cover. Dissolved $\mathrm{C}, \mathrm{N}, \mathrm{P}, \mathrm{F}^{-}$, and $\mathrm{I}^{-}$exports in the more urban watersheds could have also been more variable due to runoff from impervious surfaces and/or increased contributions from storm drains (Bernhardt et al., 2008; Hatt et al., 2004) and elsewhere in the stream corridor (i.e., sewage leaks) during storms, as shown in other studies (Divers et al., 2014; Kaushal et al., 2011; Phillips and Chalmers, 2009). We also found pulses in atmospheric $\mathrm{NO}_{3}^{-}$sources (as indicated by $\delta^{18} \mathrm{O}-\mathrm{NO}_{3}^{-}$) during storms in the more urban watersheds, similar to Kaushal et al. (2011). The attenuation of peak discharge due to stream restoration observed at MBR, which reconnected the stream with the floodplain is likely a large factor in why MBR had comparatively less pulses in $\mathrm{C}$ and nutrient exports. Also the stabilization and replacement of sewer pipes along the restored stream (Doheny et al., 2006; Mayer et al., 2010; US EPA, 2009) likely reduced the potential for $\mathrm{C}$ and nutrients to leak into the restored stream. Similarly, the upland stormwater management features and less \% ISC at RRN likely helped to dampen the flows and pulses in $\mathrm{C}$ and nutrient exports at this site compared to the more urban sites (DRN and PMR).

Based on the nutrient duration curves and the F75 metrics, the more urban watersheds (PMR and DRN) had greater exports of $\mathrm{N}, \mathrm{P}$, and wastewater indicator anions $\left(\mathrm{F}^{-}, \mathrm{I}^{-}\right)$during higher flows compared to sites with lower \% ISC and greater stormwater management (RRN) or stream restoration (MBR). Other studies also show elevated nutrient exports during higher flows in urban watersheds (Duan et al., 2012; Kaushal et al., 2014b; Shields et al., 2008). The higher $\mathrm{C}, \mathrm{N}$, and $\mathrm{P}$ exports during baseflow at the restored stream (MBR) and the least urban stream (RRN) compared to the urban degraded watersheds (DRN and PMR) likely correspond with there being less peak flow discharge, based on the hydrologic flashiness results, and also greater groundwater recharge at these sites, due to less impervious surface cover, greater SWM systems, or floodplain reconnection (Bohnke et al., 2002; Boyer and Kieser, 2012; Cendon et al., 2010; Hester and Gooseff, 2010). Overall, the sources, fluxes, and flowpaths of groundwater across streamflow should be considered in management efforts to improve stream restoration strategies for reducing nitrogen exports. 


\section{Conclusion}

Our results demonstrate that stream restoration and sewers influence the local variability of $\mathrm{C}$ and nutrient sources and fluxes among urban watersheds within the same city. Urban sewer infrastructure also influences sources, fluxes, and flowpaths of water, carbon, and nutrients over time and should explicitly be considered as part of the urban hydrologic cycle (Kaushal et al., 2014c, 2015; Risch et al., 2015). $\mathrm{NO}_{3}^{-}$ isotopes, $\mathrm{C}$ quality, and the fluoride and iodide tracer data suggest that sources of $\mathrm{N}$ and $\mathrm{C}$ within the stream corridor, such as leaky sanitary sewers and storm drain inputs, strongly influence the amount and timing of exports. Previous work has focused on upland stormwater management, but additional consideration of nonpoint sources in close proximity to streams and groundwater is also warranted in stream restoration strategies. Because gravity-fed sewers often follow stream channels, restored streams can be redesigned to better protect sewers from damage and further erosion as a management priority (Mayer et al., 2010). Consequently, effective management of urban streams may require upgrading or repairing leaks in sanitary infrastructure in the stream corridor to reduce these major sources, in combination with stream restoration or stormwater management strategies for dampening flashy hydrology and minimizing connected impervious surfaces in the watershed. These combined strategies could then help to reduce nutrient exports during both baseflow and stormflow.

Potential stream restoration strategies to reduce $\mathrm{C}$ and nutrient export include reducing the velocity of water and allowing overbank flow through floodplain reconnection, increasing retention of groundwater, providing sustainable sources of labile organic $\mathrm{C}$, reducing imperviousness in the watershed, or daylighting streams. More research is needed to assess the effectiveness of stormwater retrofits in older urban watersheds at mitigating stream degradation and improving water quality. Managing nutrient export from aging urban watersheds will require better knowledge of sources across hydrologic variability, particularly due to groundwater contamination from leaky sewers and other urban piped infrastructure.

\section{Data availability}

Data used for the research in this paper is available through the 4TU.Centre (2016) at the following URL and DOI: http://dx.doi.org/10.4121/uuid: 363c6b7d-09dc-4a96-8d19-3eaa6b9a7841 as well as from NOAA (2014) at http://www.ncdc.noaa.gov/cdo-web

\section{Information about the Supplement}

The following information can be found in the Supplement:

- additional details on methods;

- additional site information and site map;

- table of mean annual $\mathrm{C}$ and nutrient concentrations for each watershed;

- table of flashiness metrics for mean daily carbon, nitrogen, and phosphorus exports;

- table of flashiness metrics for routinely sampled concentrations;

- table of flashiness metrics for water and nitrate sources;

- table of flashiness metrics for carbon source metrics;

- flow duration curves for each site;

- comparison of nutrient concentrations over time at each site;

- water isotope comparison; and

- seasonal relationship between $\delta^{15} \mathrm{~N}^{-\mathrm{NO}_{3}^{-}}$vs. $\delta^{18} \mathrm{O}-$ $\mathrm{NO}_{3}^{-}$.

\section{The Supplement related to this article is available online at doi:10.5194/hess-20-3419-2016-supplement.}

Author contributions. This paper is based on work from Michael Pennino's PhD dissertation. Michael Pennino collected water samples, conducted data analysis, and wrote the manuscript. Sujay Kaushal contributed to the study design, and provided helpful feedback on data analysis and manuscript writing. Paul Mayer contributed to study design, coordinated water sample laboratory analysis, and contributed to manuscript revisions. Ryan Utz helped with data processing and statistical analysis, and Curtis Cooper collected the data for the comparison of pre- and post-restoration hydrologic response and analyzed the relationship between effective precipitation (Ppt) and effective peak discharge $\left(Q_{\mathrm{pk}}\right)$.

Acknowledgements. This research was supported by EPA NNEMS Award 2010-309; the NSF Graduate Research Fellowship Program under grant no. DGE-1144243; NSF Awards DGE 0549469, EF-0709659, DBI 0640300, CBET 1058502, CBET 1058038, and EAR 1521224; NASA grant NASA NNX11AM28G; Maryland Sea Grant Awards SA7528085-U, R/WS-2, and NA05OAR4171042; and Baltimore Ecosystem Study LTER project (NSF DEB1027188). We thank Tiana Pennino for field assistance, Garth Lindner for providing rating curves for two of the stream gauges, Stu Schwartz for extensive guidance on statistical analysis for 
nutrient export calculations, and Steve Stewart and Robert Hirsch from the Baltimore County Department of Environmental Protection and Sustainability for providing stormwater management data. Claire Welty and Andrew Miller provided help interpreting water isotope and streamflow data, respectively, and helpful suggestions and discussions on an earlier version of the manuscript. The US Environmental Protection Agency, through its Office of Research and Development, funded and managed, or partially funded and collaborated in, the research described herein. It has been subjected to the agency's peer and administrative review and has been approved for external publication. Any opinions expressed in this paper are those of the author(s) and do not necessarily reflect the views of the agency, therefore, no official endorsement should be inferred. Any mention of trade names or commercial products does not constitute endorsement or recommendation for use.

Edited by: A. Butturini

Reviewed by: two anonymous referees

\section{References}

4TU.Centre: Stream restoration and sanitary infrastructure alter sources and fluxes of water, carbon, and nutrients in urban watersheds - synthesis file, available at: http://dx.doi.org/10.4121/ uuid:363c6b7d-09dc-4a96-8d19-3eaa6b9a7841, last access: 22 August 2016.

Aitkenhead-Peterson, J. A., Alexander, J. E., and Clair, T. A.: Dissolved organic carbon and dissolved organic nitrogen export from forested watersheds in Nova Scotia: Identifying controlling factors, Global Biogeochem. Cy., 19, GB4016, doi:10.1029/2004GB002438, 2005.

Arango, C. P. and Tank, J. L.: Land use influences the spatiotemporal controls on nitrification and denitrification in headwater streams, J. N. Am. Benthol. Soc., 27, 90-107, 2008.

Baker, A.: Fluorescence excitation-emission matrix characterization of some sewage-impacted rivers, Environ. Sci. Technol., 35, 948-953, 2001.

Baker, D. B., Richards, R. P., Loftus, T. T., and Kramer, J. W.: A new flashiness index: Characteristics and applications to midwestern rivers and streams, J. Am. Water Resour. As., 40, 503-522, 2004.

Banach, K., Banach, A. M., Lamers, L. P. M., De Kroon, H., Bennicelli, R. P., Smits, A. J. M., and Visser, E. J. W.: Differences in flooding tolerance between species from two wetland habitats with contrasting hydrology: implications for vegetation development in future floodwater retention areas, Ann. Botany-London, 103, 341-351, 2009.

Bernhardt, E. S., Palmer, M. A., Allan, J. D., Alexander, G., Barnas, K., Brooks, S., Carr, J., Clayton, S., Dahm, C., Follstad-Shah, J., Galat, D., Gloss, S., Goodwin, P., Hart, D., Hassett, B., Jenkinson, R., Katz, S., Kondolf, G. M., Lake, P. S., Lave, R., Meyer, J. L., O'Donnell, T. K., Pagano, L., Powell, B., and Sudduth, E.: Ecology - Synthesizing US river restoration efforts, Science, 308, 636-637, 2005.

Bernhardt, E. S., Band, L. E., Walsh, C. J., and Berke, P. E.: Understanding, managing, and minimizing urban impacts on surface water nitrogen loading, Ann. Ny. Acad. Sci., 1134, 61-96, 2008.

Bettez, N. D. and Groffman, P. M.: Denitrification Potential in Stormwater Control Structures and Natural Riparian Zones in an Urban Landscape, Environ. Sci. Technol., 46, 10909-10917, 2012.

Bhaskar, A. S. and Welty, C.: Water Balances along an Urban-toRural Gradient of Metropolitan Baltimore, 2001-2009, Environ. Eng. Geosci., 18, 37-50, 2012.

Bohnke, R., Geyer, S., and Kowski, P.: Using environmental isotopes $\mathrm{H}-2$ and $\mathrm{O}-18$ for identification of infiltration processes in floodplain ecosystems of the river Elbe, Isot. Environ. Healt. S., 38, 1-13, 2002.

Bowes, M. J., House, W. A., Hodgkinson, R. A., and Leach, D. V.: Phosphorus-discharge hysteresis during storm events along a river catchment: the River Swale, UK, Water Res., 39, 751-762, 2005.

Boyer, K. B. and Kieser, M. S.: Uban stormwater mangement-an MS4 success story for western Michigan University, J. Green Build., 7, 28-39, 2012.

Brabec, E., Schulte, S., and Richards, P. L.: Impervious surfaces and water quality: A review of current literature and its implications for watershed planning, J. Plan. Lit., 16, 499-514, 2002.

Buda, A. R. and DeWalle, D. R.: Dynamics of stream nitrate sources and flow pathways during stormflows on urban, forest and agricultural watersheds in central Pennsylvania, USA, Hydrol. Process., 23, 3292-3305, 2009.

Bukaveckas, P. A.: Effects of channel restoration on water velocity, transient storage, and nutrient uptake in a channelized stream, Environ. Sci. Technol., 41, 1570-1576, 2007.

Bullock, S. H., Escoto-Rodriguez, M., Smith, S. V., and Hinojosa, A.: Carbon Flux of an Urban System in Mexico, J. Ind. Ecol., 15, 512-526, 2011.

Burns, D. A., Boyer, E. W., Elliott, E. M., and Kendall, C.: Sources and Transformations of Nitrate from Streams Draining Varying Land Uses: Evidence from Dual Isotope Analysis, J. Environ. Qual., 38, 1149-1159, 2009.

Butturini, A. and Sabater, F.: Importance of transient storage zones for ammonium and phosphate retention in a sandy-bottom Mediterranean stream, Freshwater Biol., 41, 593-603, 1999.

Carey, R. O., Wollheim, W. M., Mulukutla, G. K., and Mineau, M. M.: Characterizing Storm-Event Nitrate Fluxes in a Fifth Order Suburbanizing Watershed Using In Situ Sensors, Environ. Sci. Technol., 48, 7756-7765, 2014.

Casciotti, K. L., Sigman, D. M., Hastings, M. G., Bohlke, J. K., and Hilkert, A.: Measurement of the oxygen isotopic composition of nitrate in seawater and freshwater using the denitrifier method, Anal. Chem., 74, 4905-4912, 2002.

Cendon, D. I., Larsen, J. R., Jones, B. G., Nanson, G. C., Rickleman, D., Hankin, S. I., Pueyo, J. J., and Maroulis, J.: Freshwater recharge into a shallow saline groundwater system, Cooper Creek floodplain, Queensland, Australia, J. Hydrol., 392, 150 163, 2010.

Coble, P. G.: Characterization of marine and terrestrial DOM in seawater using excitation emission matrix spectroscopy, Mar. Chem., 51, 325-346, 1996.

Cohn, T. A.: Recent advances in statistical methods for the estimation of sediment and nutrient transport in rivers, Rev. Geophys., 33, 1117-1123, 1995.

Cooper, C., Mayer, P. M., and Faulkner, B.: Effects of road salts on groundwater and surface water dynamics of sodium and chloride in an urban restored stream, Biogeochemistry, 121, 149-161, doi:10.1007/s10533-014-9968-z, 2014. 
Cory, R. M. and McKnight, D. M.: Fluorescence spectroscopy reveals ubiquitous presence of oxidized and reduced quinones in dissolved organic matter, Environ. Sci. Technol., 39, 8142-8149, 2005.

Cory, R. M., Miller, M. P., McKnight, D. M., Guerard, J. J., and Miller, P. L.: Effect of instrument-specific response on the analysis of fulvic acid fluorescence spectra, Limnol. Oceanogr.-Meth., 8, 67-78, 2010.

Craig, Harmon: Isotopic Variations in Meteoric Waters, American Association for the Advancement of Science, 133, 1702-1703, 1961.

Darcan, S., Unak, P., Yalman, O., Lambrecht, F. Y., Biber, F. Z., Goksen, D., and Coker, M.: Determination of iodine concentration in urine by isotope dilution analysis and thyroid volume of school children in the west coast of Turkey after mandatory salt iodization, Clin. Endocrinology, 63, 543-548, 2005.

Dean, H. T., Arnold, F. A., Jay, P., and Knutson, J. W.: Studies on mass control of dental caries through fluoridation of the public water supply, Public Health Rep., 65, 1403-1408, 1950.

Dillon, P. J. and Molot, L. A.: Effect of landscape form on export of dissolved organic carbon, iron, and phosphorus from forested stream catchments, Water Resour. Res., 33, 2591-2600, 1997.

Divers, M. T., Elliott, E. M., and Bain, D. J.: Constraining Nitrogen Inputs to Urban Streams from Leaking Sewers Using Inverse Modeling: Implications for Dissolved Inorganic Nitrogen (DIN) Retention in Urban Environments, Environ. Sci. Technol., 47, 1816-1823, 2013.

Divers, M. T., Elliott, E. M., and Bain, D. J.: Quantification of Nitrate Sources to an Urban Stream Using Dual Nitrate Isotopes, Environ. Sci. Technol., 48, 10580-10587, 2014.

Doheny, E. J., Starsoneck, R. J., Striz, E. A., and Mayer., P. M.: Watershed characteristics and pre-restoration surface-water hydrology of Minebank Run, Baltimore County, Maryland, water years 2002-04, USGS Scientific Investigations Rep. 2006-5179, USGS, Reston, VA, USA, 2006.

Duan, S. W., Kaushal, S. S., Groffman, P. M., Band, L. E., and Belt, K. T.: Phosphorus export across an urban to rural gradient in the Chesapeake Bay watershed, J. Geophys. Res.-Biogeo., 117, 2012.

Duan, S. W., Delaney-Newcomb, K., Kaushal, S. S., Findlay, S. E. G., and Belt, K. T.: Potential effects of leaf litter on water quality in urban watersheds, Biogeochemistry, 121, 61-80, 2014.

Duerksen, C. J., Snyder, C., and ebrary Inc.: Nature-friendly communities habitat protection and land use, Island Press, Washington, DC, USA, 2005.

Efron, B. and Tibshirani, R.: Bootstrap methods for standard errors, confidence intervals, and other measures of statistical accuracy, Stat. Sci., 1986, 54-75, 1986.

Ekklesia, E., Shanahan, P., Chua, L. H. C., and Eikaas, H. S.: Temporal variation of faecal indicator bacteria in tropical urban storm drains, Water Res., 68, 171-181, 2015.

Emerson, C. H., Welty, C., and Traver, R. G.: Watershed-scale evaluation of a system of storm water detention basins, J. Hydrol. Eng., 10, 237-242, 2005.

Filoso, S. and Palmer, M. A.: Assessing stream restoration effectiveness at reducing nitrogen export to downstream waters, Ecol. Appl., 21, 1989-2006, 2011.

Gat, J. R.: Oxygen and hydrogen isotopes in the hydrologic cycle, Annu. Rev. Earth Pl. Sci., 24, 225-262, 1996.
Gehr, R. and Leduc, R.: Assessing effluent fluoride concentrations following physicochemical waste-water treatment, Can. J. Civil Eng., 19, 649-659, 1992.

Gilbert, R. O.: 6.5 Sen's Nonparametric Estimator of Slope, in: Statistical Methods for Environmental Pollution Monitoring, John Wiley and Sons, Canada, 1987.

Goetz, S. J., Wright, R. K., Smith, A. J., Zinecker, E., and Schaub, E.: IKONOS imagery for resource management: Tree cover, impervious surfaces, and riparian buffer analyses in the midAtlantic region, Remote Sens. Environ., 88, 195-208, 2003.

Goldman, J. H., Rounds, S. A., and Needoba, J. A.: Applications of Fluorescence Spectroscopy for Predicting Percent Wastewater in an Urban Stream, Environ. Sci. Technol., 46, 4374-4381, 2012.

Greenman-Pedersen Inc.: Minebank Run II stream restoration design report and 100-year floodplain impact analysis, Appendices, Laurel, MD, USA, 10 pp., 2003.

Groffman, P. M., Law, N. L., Belt, K. T., Band, L. E., and Fisher, G. T.: Nitrogen fluxes and retention in urban watershed ecosystems, Ecosystems, 7, 393-403, 2004.

Groffman, P. M., Dorsey, A. M., and Mayer, P. M.: N processing within geomorphic structures in urban streams, J. N. Am. Benthol. Soc., 24, 613-625, 2005.

Hall, S. J., Weintraub, S. R., Eiriksson, D., Brooks, P. D., Baker, M. A., Bowen, G. J., and Bowling, D. R.: Stream Nitrogen Inputs Reflect Groundwater Across a Snowmelt-Dominated Montane to Urban Watershed, Environ. Sci. Technol., 50, 1137-1146, 2016.

Harris, C., Oom, B. M., and Diamond, R. E.: A preliminary investigation of the oxygen and hydrogen isotope hydrology of the greater Cape Town area and an assessment of the potential for using stable isotopes as tracers, Water Sa., 25, 15-24, 1999.

Harrison, M. D., Groffman, P. M., Mayer, P. M., Kaushal, S. S., and Newcomer, T. A.: Denitrification in Alluvial Wetlands in an Urban Landscape, J. Environ. Qual., 40, 634-646, 2011.

Harrison, M. D., Miller, A. J., Groffman, P. M., Mayer, P. M., and Kaushal, S. S.: Hydrologic controls on nitrogen and phosphorous dynamics in relict oxbow wetlands adjacent to an urban restored stream, J. Am. Water Resour. As., 50, 1365-1382, 2014.

Hatt, B. E., Fletcher, T. D., Walsh, C. J., and Taylor, S. L.: The influence of urban density and drainage infrastructure on the concentrations and loads of pollutants in small streams, Environ. Manage., 34, 112-124, 2004.

Helsel, D. R. and Hirsch, R. M.: Statistical methods in water resources, Elsevier, US Geological Survey, Print ISBN: 9780444885289, Electronic ISBN: 9780080875088, 1992.

Helsel, D. R. and Hirsch, R. M.: Statistical methods in water resources. In: Techniques of Water-Resources Investigations of the United States Geological Survey Book 4, Hydrologic Analysis and Interpretation, US Geological Survey, 2002.

Hester, E. T. and Gooseff, M. N.: Moving Beyond the Banks: Hyporheic Restoration Is Fundamental to Restoring Ecological Services and Functions of Streams, Environ. Sci. Technol., 44, 1521-1525, 2010.

Hill, A. R.: Stream phosphorus exports from watersheds with contrasting land uses in southern Ontario, Water Resour. Bull., 17, 627-634, 1981.

Hoffmann, C. C., Kronvang, B., and Audet, J.: Evaluation of nutrient retention in four restored Danish riparian wetlands, Hydrobiologia, 674, 5-24, 2011. 
Hope, D., Billett, M. F., and Cresser, M. S.: A review of the export of carbon in river water - fluxes and processes, Environ. Pollut., 84, 301-324, 1994.

Horowitz, A. J.: Monitoring suspended sediments and associated chemical constituents in urban environments: lessons from the city of Atlanta, Georgia, USA Water Quality Monitoring Program, J. Soil. Sediment., 9, 342-363, 2009.

Hudson, N., Baker, A., Ward, D., Reynlds, D. M., Brunsdon, C., Carliell-Marquet, C., and Browning, S.: Can fluorescence spectrometry be used as a surrogate for the Biochemical Oxygen Demand (BOD) test in water quality assessment? An example from South West England, Sci. Total Environ., 391, 149-158, 2008.

Huguet, A., Vacher, L., Relexans, S., Saubusse, S., Froidefond, J. M., and Parlanti, E.: Properties of fluorescent dissolved organic matter in the Gironde Estuary, Org. Geochem., 40, 706-719, 2009

Julian, J. P. and Gardner, R. H.: Land cover effects on runoff patterns in eastern Piedmont (USA) watersheds, Hydrol. Process., 28, 1525-1538, 2014.

Kaushal, S. S. and Belt, K. T.: The urban watershed continuum: evolving spatial and temporal dimensions, Urban Ecosystems, 15, 409-435, 2012.

Kaushal, S. S., Groffman, P. M., Band, L. E., Shields, C. A., Morgan, R. P., Palmer, M. A., Belt, K. T., Swan, C. M., Findlay, S. E. G., and Fisher, G. T.: Interaction between urbanization and climate variability amplifies watershed nitrate export in Maryland, Environ. Sci. Technol., 42, 5872-5878, 2008a.

Kaushal, S. S., Groffman, P. M., Mayer, P. M., Striz, E., and Gold, A. J.: Effects of stream restoration on denitrification in an urbanizing watershed, Ecol. Appl., 18, 789-804, 2008b.

Kaushal, S. S., Groffman, P. M., Band, L. E., Elliott, E. M., Shields, C. A., and Kendall, C.: Tracking Nonpoint Source Nitrogen Pollution in Human-Impacted Watersheds, Environ. Sci. Technol., 45, 8225-8232, 2011.

Kaushal, S. S., Delaney-Newcomb, K., Findlay, S. E. G., Newcomer, T. A., Duan, S., Pennino, M. J., Sivirichi, G. M., SidesRaley, A. M., Walbridge, M. R., and Belt, K. T.: Longitudinal patterns in carbon and nitrogen fluxes and stream metabolism along an urban watershed continuum, Biogeochemistry, 121, 2344, doi:10.1007/s10533-014-9979-9, 2014a.

Kaushal, S. S., Mayer, P. M., Vidon, P. G., Smith, R. M., Pennino, M. J., Duan, S., Newcomer, T. A., Welty, C., and Belt, K. T.: Land use and climate variability amplify carbon, nutrient, and contaminant pulses: a review with management implications, J. Am. Water Resour. As., 50, 585-614, 2014b.

Kaushal, S. S., McDowell, W. H., and Wollheim, W. M.: Tracking evolution of urban biogeochemical cycles: past, present, and future, Biogeochemistry, 121, 1-21, 2014c.

Kaushal, S. S., McDowell, W. H., Wollheim, W. M., Johnson, T. A. N., Mayer, P. M., Belt, K. T., and Pennino, M. J.: Urban Evolution: The Role of Water, Water, 7, 4063-4087, 2015.

Kendall, C. and Coplen, T. B.: Distribution of oxygen-18 and deuterium in river waters across the United States, Hydrol. Process., 15, 1363-1393, 2001.

Kendall, C., Elliott, E. M., and Wankel, S. D.: Tracing anthropogenic inputs of nitrogen to ecosystems, Stable Isotopes in Ecology and Environmental Science, 2nd Edition, 375-449, doi:10.1002/9780470691854.ch12, 2007.
Klocker, C. A., Kaushal, S. S., Groffman, P. M., Mayer, P. M., and Morgan, R. P.: Nitrogen uptake and denitrification in restored and unrestored streams in urban Maryland, USA, Aquat. Sci., 71, 411-424, 2009.

Konrad, C. P., Booth, D. B., and Burges, S. J.: Effects of urban development in the Puget Lowland, Washington, on interannual streamflow patterns: Consequences for channel form and streambed disturbance, Water Resour. Res., 41, W07009, doi:10.1029/2005WR004097, 2005.

Kurth, A.-M., Weber, C., and Schirmer, M.: How effective is river restoration in re-establishing groundwater-surface water interactions? - A case study, Hydrol. Earth Syst. Sci., 19, 2663-2672, doi:10.5194/hess-19-2663-2015, 2015

Lamouroux, N., Gore, J. A., Lepori, F., and Statzner, B.: The ecological restoration of large rivers needs science-based, predictive tools meeting public expectations: an overview of the Rhone project, Freshwater Biol., 60, 1069-1084, 2015.

Leopold, L. B.: Hydrology for urban land planning: a guidebook on the hydrologic effects of urban land use, US Geological Survey Circular 554, US Geological Survey, Washington, DC, USA 1968.

Lewis, D. B. and Grimm, N. B.: Hierarchical regulation of nitrogen export from urban catchments: Interactions of storms and landscapes, Ecol. Appl., 17, 2347-2364, 2007.

Li, W. H., Liu, Y. X., Wang, W., Sheng, G. P., Yu, H. Q., and Shuai, L.: Analysis of Samples from Wastewater Treatment Plant and Receiving Waters Using EEM Fluorescence Spectroscopy, Spectrosc. Spect. Anal., 35, 940-945, 2015.

Lindner, G. A. and Miller, A. J.: Numerical Modeling of StageDischarge Relationships in Urban Streams, J. Hydrol. Eng., 17, 590-596, 2012.

Line, D. E., White, N. M., Osmond, D. L., Jennings, G. D., and Mojonnier, C. B.: Pollutant export from various land uses in the upper Neuse River Basin, Water Environ. Res., 74, 100-108, 2002.

Lloyd, C. E. M., Freer, J. E., Collins, A. L., Johnes, P. J., and Jones, J. I.: Methods for detecting change in hydrochemical time series in response to targeted pollutant mitigation in river catchments, J. Hydrol., 514, 297-312, 2014.

Loperfido, J. V., Noe, G. B., Jarnagin, S. T., and Hogan, D. M.: Effects of distributed and centralized stormwater best management practices and land cover on urban stream hydrology at the catchment scale, J. Hydrol., 519, 2584-2595, 2014.

Mayer, P. M., Reynolds, S. K., McCutchen, M. D., and Canfield, T. J.: Meta-analysis of nitrogen removal in riparian buffers, J Environ. Qual., 36, 1172-1180, 2007.

Mayer, P. M., Groffman, P. M., Striz, E. A., and Kaushal, S. S.: Nitrogen Dynamics at the Groundwater-Surface Water Interface of a Degraded Urban Stream, J. Environ. Qual., 39, 810-823, 2010.

McKnight, D. M., Boyer, E. W., Westerhoff, P. K., Doran, P. T., Kulbe, T., and Andersen, D. T.: Spectrofluorometric characterization of dissolved organic matter for indication of precursor organic material and aromaticity, Limnol. Oceanogr., 46, 38-48, 2001.

McMillan, S. K. and Vidon, P. G.: Taking the pulse of stream restoration practices: moving towards healthier streams, Hydrol. Process., 28, 398-400, 2014.

Meierdiercks, K. L., Smith, J. A., Baeck, M. L., and Miller, A. J.: Analyses of urban drainage network structure and its impact on 
hydrologic response, J. Am. Water Resour. As., 46, 932-943, 2010.

Mulholland, P. J. and Kuenzler, E. J.: Organic-carbon export from upland and forested wetland watersheds, Limnol. Oceanogr., 24, 960-966, 1979.

Mulholland, P. J., Marzolf, E. R., Webster, J. R., Hart, D. R., and Hendricks, S. P.: Evidence that hyporheic zones increase heterotrophic metabolism and phosphorus uptake in forest streams, Limnol. Oceanogr., 42, 443-451, 1997.

Newcomer, J. T. A., Kaushal, S. S., Mayer, P. M., and Grese, M.: Effects of stormwater management and stream restoration on watershed nitrogen retention., Biogeochemistry, 121, 81-106, doi:10.1007/s10533-014-9999-5, 2014.

Newcomer, T. A., Kaushal, S. S., Mayer, P. M., Shields, A. R., Canuel, E. A., Groffman, P. M., and Gold, A. J.: Influence of natural and novel organic carbon sources on denitrification in forest, degraded urban, and restored streams, Ecol. Monogr., 82, 449466, 2012.

Newcomer-Johnson, T. A., Kaushal, S. S., Mayer, P. M., Smith, R. M., and Sivirichi, G. M.: Nutrient Retention in Restored Streams and Rivers: A Global Review and Synthesis, Water, 8, 116, doi:10.3390/w8040116, 2016.

Nixon, S. W., Ammerman, J. W., Atkinson, L. P., Berounsky, V. M., Billen, G., Boicourt, W. C., Boynton, W. R., Church, T. M., Ditoro, D. M., Elmgren, R., Garber, J. H., Giblin, A. E., Jahnke, R. A., Owens, N. J. P., Pilson, M. E. Q., and Seitzinger, S. P.: The fate of nitrogen and phosphorus at the land sea margin of the North Atlantic Ocean, Biogeochemistry, 35, 141-180, 1996.

NOAA: The National Atmospheric and Ocean Administration's National Climatic Data Center, available at: http://www.ncdc.noaa. gov/cdo-web, last access: 17 November 2014.

Old, G. H., Leeks, G. J. L., Packman, J. C., Smith, B. P. G., Lewis, S., and Hewitt, E. J.: River flow and associated transport of sediments and solutes through a highly urbanised catchment, Bradford, West Yorkshire, Sci. Total Environ., 360, 98-108, 2006.

Passeport, E., Vidon, P., Forshay, K. J., Harris, L., Kaushal, S. S., Kellogg, D. Q., Lazar, J., Mayer, P., and Stander, E. K.: Ecological Engineering Practices for the Reduction of Excess Nitrogen in Human-Influenced Landscapes: A Guide for Watershed Managers, Environ. Manage., 51, 392-413, 2013.

Paul, M. J. and Meyer, J. L.: Streams in the urban landscape, Annu. Rev. Ecol. Syst., 32, 333-365, 2001.

Pennino, M. J., Kaushal, S. S., Beaulieu, J. J., Mayer, P. M., and Arango, C. P.: Effects of urban stream burial on nitrogen uptake and ecosystem metabolism: implications for watershed nitrogen and carbon fluxes, Biogeochemistry, 121, 247-269, 2014.

Petrone, K. C.: Catchment export of carbon, nitrogen, and phosphorus across an agro-urban land use gradient, Swan-Canning River system, southwestern Australia, J. Geophys. Res.-Biogeo., 115, G01016, doi:10.1029/2009JG001051, 2010.

Petrone, K. C., Fellman, J. B., Hood, E., Donn, M. J., and Grierson, P. F.: The origin and function of dissolved organic matter in agrourban coastal streams, J. Geophys. Res.-Biogeo., 116, G01028, doi:10.1029/2010JG001537, 2011.

Phillips, D. L.: Mixing models in analyses of diet using multiple stable isotopes: a critique, Oecologia, 127, 166-170, 2001.

Phillips, P. and Chalmers, A.: Wastewater effluent, combined sewer overflows, and other sources of organic compounds to lake champlain, J. Am. Water Resour. As., 45, 45-57, 2009.
Poff, N. L., Bledsoe, B. P., and Cuhaciyan, C. O.: Hydrologic variation with land use across the contiguous United States: Geomorphic and ecological consequences for stream ecosystems, Geomorphology, 79, 264-285, 2006a.

Poff, N. L., Bledsoe, B. P., and Cuhaciyan, C. O.: Hydrologic variation with land use across the contiguous United States: Geomorphic and ecological consequences for stream ecosystems, Geomorphology, 79, 264-285, 2006b.

Qian, Y., Migliaccio, K. W., Wan, Y. S., and Li, Y. C.: Trend analysis of nutrient concentrations and loads in selected canals of the southern indian river lagoon, florida, Water Air Soil Poll., 186, 195-208, 2007.

R Development Core Team: available at: http://www.R-project.org, last access: 23 September 2013.

Risch, E., Gutierrez, O., Roux, P., Boutin, C., and Corominas, L.: Life cycle assessment of urban wastewater systems: Quantifying the relative contribution of sewer systems, Water Res., 77, 35-48, 2015.

Roley, S. S., Tank, J. L., and Williams, M. A.: Hydrologic connectivity increases denitrification in the hyporheic zone and restored floodplains of an agricultural stream, J. Geophys. Res.-Biogeo., 117, G00N04, doi:10.1029/2012JG001950, 2012.

Rose, S.: The effects of urbanization on the hydrochemistry of base flow within the Chattahoochee River Basin (Georgia, USA), J. Hydrol., 341, 42-54, 2007.

Runkel, R. L., Crawford, C. G., and Cohn, T. A.: Load Estimator (LOADEST): A FORTRAN Program for Estimating Constituent Loads in Streams and Rivers. In: Techniques and Methods Book 4, US Geological Survey, Reston, VA, USA, 2004.

Runkel, R. L.: Revisions to LOADEST, available at: http://water. usgs.gov/software/loadest/doc, last access: 15 March 2013.

Rustomji, P. and Wilkinson, S. N.: Applying bootstrap resampling to quantify uncertainty in fluvial suspended sediment loads estimated using rating curves, Water Resour. Res., 44, W09435, doi:10.1029/2007WR006088, 2008.

Ryan, R. J., Welty, C., and Larson, P. C.: Variation in surface watergroundwater exchange with land use in an urban stream, J. Hydrol., 392, 1-11, 2010.

Schwartz, S. S. and Naiman, D. Q.: Bias and variance of planning level estimates of pollutant loads, Water Resour. Res., 35, 34753487, 1999.

Shields, C. A., Band, L. E., Law, N., Groffman, P. M., Kaushal, S. S., Savvas, K., Fisher, G. T., and Belt, K. T.: Streamflow distribution of non-point source nitrogen export from urban-rural catchments in the Chesapeake Bay watershed, Water Resour. Res., 44, W09416, doi:10.1029/2007WR006360, 2008.

Sigman, D. M., Casciotti, K. L., Andreani, M., Barford, C., Galanter, M., and Bohlke, J. K.: A bacterial method for the nitrogen isotopic analysis of nitrate in seawater and freshwater, Anal. Chem., 73, 4145-4153, 2001.

Silva, S. R., Ging, P. B., Lee, R. W., Ebbert, J. C., Tesoriero, A. J., and Inkpen, E. L.: Forensic applications of nitrogen and oxygen isotopes in tracing nitrate sources in urban environments, Environ. Forensics, 3, 125-130, 2002.

Sivirichi, G. M., Kaushal, S. S., Mayer, P. M., Welty, C., Belt, K. T., Newcomer, T. A., Newcomb, K. D., and Grese, M. M.: Longitudinal variability in streamwater chemistry and carbon and nitrogen fluxes in restored and degraded urban stream networks, J. Environ. Monitor., 13, 288-303, 2011. 
Smith, B. K. and Smith, J. A.: The Flashiest Watersheds in the Contiguous United States, J. Hydrometeorol., 16, 2365-2381, 2015.

Smith, B. K., Smith, J. A., Baeck, M., Villarini, L. G., and Wright, D. B.: Spectrum of storm event hydrologic response in urban watersheds, Water Resour. Res., 49, 2649-2663, 2013.

Smith, B. K., Smith, J. A., Baeck, M. L., and Miller, A. J.: Exploring storage and runoff generation processes for urban flooding through a physically based watershed model, Water Resour. Res., 51, 1552-1569, 2015.

Smith, R. M. and Kaushal, S. S.: Carbon cycle of an urban watershed: exports, sources, and metabolism, Biogeochemistry, 126, 173-195, 2015.

Sobota, D. J., Harrison, J. A., and Dahlgren, R. A.: Influences of climate, hydrology, and land use on input and export of nitrogen in California watersheds, Biogeochemistry, 94, 43-62, 2009.

Stolpe, B., Guo, L., Shiller, A. M., and Hassellov, M.: Size and composition of colloidal organic matter and trace elements in the Mississippi River, Pearl River and the northern Gulf of Mexico, as characterized by flow field-flow fractionation, Mar. Chem., $118,119-128,2010$.

Strauss, E. A. and Lamberti, G. A.: Effect of dissolved organic carbon quality on microbial decomposition and nitrification rates in stream sediments, Freshwater Biol., 47, 65-74, 2002.

Sudduth, E. B., Hassett, B. A., Cada, P., and Bernhardt, E. S.: Testing the Field of Dreams Hypothesis: functional responses to urbanization and restoration in stream ecosystems, Ecol. Appl., 21, 1972-1988, 2011a.

Sudduth, E. B., Hassett, B. A., Cada, P., and Bernhardt, E. S.: Testing the Field of Dreams Hypothesis: functional responses to urbanization and restoration in stream ecosystems, Ecol. Appl., 21, 1972-1988, 2011b.

Tate, C. M. and Meyer, J. L.: The influence of hydrologic conditions and successional state on dissolved organic-carbon export from forested watersheds, Ecology, 64, 25-32, 1983.

Tran, N. H., Hu, J. Y., Li, J. H., and Ong, S. L.: Suitability of artificial sweeteners as indicators of raw wastewater contamination in surface water and groundwater, Water Res., 48, 443-456, 2014.

US EPA: Section 319.,Nonpoint Source Program Success Story: Maryland. Restoring Stream Reduces Nitrogen in an Urbanized Watershed, EPA 841-F-09-001KK, 2009.

Utz, R. M., Eshleman, K. N., and Hilderbrand, R. H.: Variation in physicochemical responses to urbanization in streams between two Mid-Atlantic physiographic regions, Ecol. Appl., 21, 402415,2011
Walsh, C. J., Roy, A. H., Feminella, J. W., Cottingham, P. D., Groffman, P. M., and Morgan, R. P.: The urban stream syndrome: current knowledge and the search for a cure, J. N. Am. Benthol. Soc., 24, 706-723, 2005a.

Walsh, C. J., Roy, A. H., Feminella, J. W., Cottingham, P. D., Groffman, P. M., and Morgan, R. P.: The urban stream syndrome: current knowledge and the search for a cure, J. N. Am. Benthol. Soc., 24, 706-723, 2005 b.

Waszkowiak, K. and Szymandera-Buszka, K.: Effect of storage conditions on potassium iodide stability in iodised table salt and collagen preparations, Int. J. Food Sci. Tech., 43, 895-899, 2008.

Williard, K. W. J., DeWalle, D. R., Edwards, P. J., and Sharpe, W. E.: O-18 isotopic separation of stream nitrate sources in mid-Appalachian forested watersheds, J. Hydrol., 252, 174-188, 2001.

Wolf, L., Zwiener, C., and Zemann, M.: Tracking artificial sweeteners and pharmaceuticals introduced into urban groundwater by leaking sewer networks, Sci. Total Environ., 430, 8-19, 2012.

Worrall, F., Davies, H., Bhogal, A., Lilly, A., Evans, M., Turner, K., Burt, T., Barraclough, D., Smith, P., and Merrington, G.: The flux of DOC from the UK - Predicting the role of soils, land use and net watershed losses, J. Hydrol., 448, 149-160, 2012.

Xu, Z. X., Wang, L. L., Yin, H. L., Li, H. Z., and Schwegler, B. R.: Source apportionment of non-storm water entries into storm drains using marker species: Modeling approach and verification, Ecol. Indic., 61, 546-557, 2016.

Yu, H. B., Song, Y. H., Gao, H. J., Liu, L., Yao, L. L., and Peng, J. F.: Applying fluorescence spectroscopy and multivariable analysis to characterize structural composition of dissolved organic matter and its correlation with water quality in an urban river, Environ. Earth Sci., 73, 5163-5171, 2015.

Ziemer, R. R. and Lisle, T. E.: Chapter 3. Hydrology, in: River Ecology and Management: Lessons from the Pacific Coastal Ecoregion, edited by: Naiman, R. J. and Bilby, R. E., Springer-Verlag, New York, NY, USA, 1998.

Zsolnay, A., Baigar, E., Jimenez, M., Steinweg, B., and Saccomandi, F.: Differentiating with fluorescence spectroscopy the sources of dissolved organic matter in soils subjected to drying, Chemosphere, 38, 45-50, 1999. 